\title{
Gibberellin Promotes Sweetpotato Root Vascular Lignification and Reduces Storage-Root Formation
}

\section{OPEN ACCESS}

Edited by:

Adriano Nunes-Nesi, Universidade Federal de Viçosa,

Brazil

Reviewed by:

Paolo Costantino,

Sapienza University of Rome,

$$
\text { Italy }
$$

Ai-Sheng Xiong,

Nanjing Agricultural University,

China

Qingchang Liu,

China Agricultural University (CAU),

China

*Correspondence:

Nurit Firon

vcfiron@volcani.agri.gov.il

Specialty section:

This article was submitted to

Plant Physiology,

a section of the journal

Frontiers in Plant Science

Received: 10 June 2019 Accepted: 23 September 2019 Published: 15 November 2019

Citation:

Singh V, Sergeeva L, Ligterink W,

Aloni R, Zemach H, Doron-

Faigenboim A, Yang J, Zhang P,

Shabtai $S$ and Firon N (2019)

Gibberellin Promotes Sweetpotato

Root Vascular Lignification and

Reduces Storage-Root Formation.

Front. Plant Sci. 10:1320.

doi: 10.3389/fp/s.2019.01320
Vikram Singh'1, Lidiya Sergeeva², Wilco Ligterink ${ }^{2}$, Roni Aloni3 ${ }^{3}$, Hanita Zemach4, Adi Doron-Faigenboim ${ }^{1}$, Jun Yang ${ }^{5}$, Peng Zhang ${ }^{6}$, Sara Shabtai ${ }^{1}$ and Nurit Firon ${ }^{1 *}$

${ }^{1}$ Department of Vegetable and Field Crops, Institute of Plant Sciences, Agricultural Research Organization, The Volcani Center, Rishon LeZion, Israel, ${ }^{2}$ Laboratory of Plant Physiology, Department of Plant Sciences, Wageningen University, Wageningen, Netherlands, ${ }^{3}$ School of Plant Sciences and Food Security, Tel Aviv University, Tel Aviv, Israel, ${ }^{4}$ Department of Fruit Tree Sciences, Institute of Plant Sciences, Agricultural Research Organization, The Volcani Center, Rishon LeZion, Israel, ${ }^{5}$ Chenshan Plant Science Research Center, Chinese Academy of Sciences, Shanghai Chenshan Botanical Garden, Shanghai, China, ${ }^{6}$ Institute of Plant Physiology \& Ecology, SIBS, Chinese Academy of Sciences, Shanghai, China

Sweetpotato yield depends on a change in the developmental fate of adventitious roots into storage-roots. The mechanisms underlying this developmental switch are still unclear. We examined the hypothesis claiming that regulation of root lignification determines storageroot formation. We show that application of the plant hormone gibberellin increased stem elongation and root gibberellin levels, while having inhibitory effects on root system parameters, decreasing lateral root number and length, and significantly reducing storageroot number and diameter. Furthermore, gibberellin enhanced root xylem development, caused increased lignin deposition, and, at the same time, decreased root starch accumulation. In accordance with these developmental effects, gibberellin application upregulated expression levels of sweetpotato orthologues of Arabidopsis vascular development regulators (IJNA075, IbVND7, and IbSND2) and of lignin biosynthesis genes (IbPAL, IbC4H, Ib4CL, IbCCOAOMT, and IbCAD), while downregulating starch biosynthesis genes (IbAGPase and IbGBSS) in the roots. Interestingly, gibberellin downregulated root expression levels of orthologues of the Arabidopsis BREVIPEDICELLUS transcription factor (IJKN2 and IbKN3), regulator of meristem maintenance. The results substantiate our hypothesis and mark gibberellin as an important player in regulation of sweetpotato root development, suggesting that increased fiber formation and lignification inhibit storageroot formation and yield. Taken together, our findings provide insight into the mechanisms underlying sweetpotato storage-root formation and provide a valuable database of genes for further research.

Keywords: gene expression, gibberellin, lignin, root anatomy, storage-root, sweetpotato, xylem, yield 


\section{HIGHLIGHTS}

Gibberellin affects sweetpotato yield, causing upregulation of root xylem development and lignin biosynthesis, together with downregulation of starch accumulation and inhibition of storage-root formation.

\section{INTRODUCTION}

Sweetpotato (Ipomoea batatas (L.) Lam., family Convolvulaceae) is the sixth most important food crop globally, after wheat, rice, maize, potato, and cassava (CIP, 2017), with 112.8 million tons produced in 2017 (FAOSTAT, 2017). Sweetpotato is a rich source of carbohydrates, vitamins, dietary fiber, and micronutrients, and is of high importance for food security and for improving the nutrition status in Asia and especially in sub-Saharan Africa. Sweetpotato can grow under marginal conditions, thus providing a good solution for nutrition in developing countries (CIP, 2017).

The most important process in sweetpotato production is storage-root (SR) formation. Sweetpotato plants are propagated through stem-cuttings that produce adventitious roots (ARs) from primordia developed on stem nodes (Ma et al., 2015). Initially, these ARs develop into white lignified roots that support development of the sweetpotato plant. Most of these initial ARs can, however, change their developmental fate and be transformed into SRs (Villordon et al., 2009). This change involves accumulation of starch and is dependent on regulatory mechanisms that are not yet well characterized (Firon et al., 2013; Ravietal., 2014). The first clear sign of the developmental transition into a SR is formation of primary and secondary cambial cells (anomalous cambium) encircling the AR primary and secondary xylem elements (Villordon et al., 2009). In SRs, cambial cells proliferation occurs, forming starch-accumulating parenchyma cells in the root vascular cylinder (Villordon et al., 2009). In roots that do not develop into SRs, intensive stele lignification is documented (Villordon et al., 2009), suggesting that stele lignification during the early phase of root development affects SR development (Togari, 1950). By performing transcriptional profiling of sweetpotato roots during SR initiation phase, we have previously suggested that down-regulation of lignin biosynthesis and up-regulation of starch biosynthesis are key events at the early stage of SR formation (Firon et al., 2013). A link between root system architecture (RSA) parameters and SR initiation and

\footnotetext{
Abbreviations: AGPase, ADP glucose pyrophosphorylase; AR, adventitious root; BP, BREVIPEDICELLUS; CAD, cinnamyl alcohol dehydrogenase; CCoAOMT, caffeoyl-CoA $\mathrm{O}$-methyltransferase; $\mathrm{C} 4 \mathrm{H}$, cinnamate 4-hydroxylase; 4CL, 4-coumarate:CoA ligase; GA, gibberellin; GAI, gibberellic acid insensitive; GBSS, granule-bound starch synthase; GID1, GA insensitive dwarf 1; GA2ox, GA 2-oxidase; GA20ox, GA 20-oxidase; GA3ox, GA 3-oxidase; HCT, p-Hydroxycinnamoyl-CoA: quinate shikimate p-hydroxycinnamoyltransferase; KNOX, Class I knotted 1-like; KO, ent-kaurene oxidase; LR, lateral root; NST/ SND, NAC secondary-wall thickening promoting factor/secondary-wallassociated NAC domain protein; PAL, phenylalanine ammonia-lyase; PB, paclobutrazol; PGM, phosphoglucomutase; $\mathrm{Ph}-\mathrm{HCl}$, phloroglucinol-HCl; RSA, root system architecture; SP, starch phosphorylase; SR, storage-root; SuSy, sucrose synthase; VND, vascular-related NAC domain; VNI2, VND-INTERACTING2; XND1, XYLEM NAC DOMAIN 1.
}

yield potential was suggested (Villordon et al., 2012; Villordon and Clark, 2014; Villordon et al., 2014). Adventitious roots that showed evidence for SR initiation had higher lateral root (LR) attributes such as LR number, length and surface area (Villordon et al., 2012). It was further suggested that in ARs with a prevalence of arrested/non-emerged LR primordia, the adjacent stellar tissue becomes lignified, rendering it incapable of undergoing swelling due to the lack of vascular and anomalous cambia development (Villordon and Clark, 2014). Thus, a relationship between RSA and the developmental fate of sweetpotato ARs was suggested.

Lignification is considered part of the plant's developmental program, being coordinated with the production of cellulose, hemicellulose, and other polysaccharides during secondary wall formation (Bonawitz and Chapple, 2010 and references therein). In Arabidopsis, significant metabolic commitment to secondary wall deposition occurs during maturation of xylem vessels, xylary fiber cells, and interfascicular fiber cells in the developing inflorescence stem (Chaffey et al., 2002; Zhong et al., 2006). Such a link between lignification and xylem development was established in numerous systems (Kaneda et al., 2008; Geng et al., 2018). In cassava roots, similar to sweetpotato, the root system consists mainly of two root types, fibrous/lignified roots that transport water and nutrients, and SRs that accumulate starch. The fibrous roots produce xylem vessels and xylem fibers, and SRs produce mainly starch-storing xylem parenchyma cells (Yang et al., 2011). Recently, a correlation was established in cassava between expression of xylem differentiation- and lignin-biosynthesisregulators, and fibrous root development (Siebers et al., 2017).

Lignification is governed mainly by genes involved in lignin biosynthesis and by master regulators of vascular development, regulating xylem, and xylem fiber cell differentiation, including members of the vascular-related NAC domain (VND) (OhashiIto et al., 2010) and NAC secondary-wall thickening promoting factor/secondary-wall-associated NAC domain protein (NST/ SND) (Zhong et al., 2006; Zhong et al., 2007). Most information on these genes is available from studies in Arabidopsis (Yamaguchi et al., 2008; Hussey et al., 2011) and wood formation (Hellmann et al., 2018). These upstream regulatory NAC domain transcription factors act as either activators or repressors of lignin biosynthesis (Taylor-Teeples et al., 2015). Among these, the positive regulators VND5, 6, and 7 are master switches of xylem cell differentiation, regulating protoxylem, and metaxylem differentiation, and secondary wall biosynthesis (Kubo et al., 2005; Yamaguchi et al., 2008; Zhou et al., 2014). SND1/NST1 and SND2 are involved in secondary cell wall formation in xylem vessels and xylem fiber differentiation (Zhong et al., 2006; Mitsuda et al., 2007; Hussey et al., 2011). The NAC domain repressor, VND-INTERACTING 2 (VNI2) negatively regulates xylem vessel formation/differentiation and represses VND7induced expression of vessel-specific genes (Yamaguchi et al., 2010). Another NAC domain repressor, XYLEM NAC DOMAIN 1 (XND1) was also shown to reduce xylem vessel differentiation and lignin accumulation (Zhao et al., 2008). Recently, VND and NST genes were suggested as potential regulators of xylem specification in cassava roots (Siebers et al., 2017). In sweetpotato, downregulation of various NAC domain transcription factors was reported during SR formation (McGregor, 2006). 
Lignin biosynthesis (being the linking of monolignol units) depends on the monolignol biosynthesis pathway, starting with deamination of phenylalanine by phenylalanine ammonialyase (PAL; the main enzyme of the phenylpropanoid pathway) (Boerjan et al., 2003). This is followed by a series of reactions, involving the following enzymes: cinnamate 4-hydroxylase $(\mathrm{C} 4 \mathrm{H}), 4$-coumarate:CoA ligase (4CL), p-hydroxycinnamoylCoA: quinate shikimate $p$-hydroxycinnamoyltransferase (HCT), caffeoyl-CoA O-methyltransferase (CCoAOMT), and cinnamyl alcohol dehydrogenase (CAD) (Raes et al., 2003). Downregulation of genes involved in lignin biosynthesis, including PAL, C4H, 4CL, HCT, CCoAOMT, and CAD was reported during sweetpotato SR formation (Firon et al., 2013; Tanaka, 2016). Moreover, up-regulation of key enzymes of the phenylpropanoid biosynthesis pathway in sweetpotato roots, by overexpressing the maize leaf color gene, was found to correlate with higher lignification, lower starch accumulation, and lower SR yield (Wang et al., 2016).

Recently, it was demonstrated that the plant hormone gibberellin (GA) is involved in root growth, secondary xylem development and lignin accumulation in carrot (Wang et al., 2015a; Wang et al., 2017). Exogenous application of $\mathrm{GA}_{3}$ was shown in Betula platyphylla to induce xylem development and expression of secondary wall biosynthesis genes (Guo et al., 2015). In Aspen, it was suggested that GA has a role in regulating early stages of xylem differentiation during wood formation (Israelsson et al., 2005). Gibberellin is known to regulate diverse plant developmental processes throughout the life cycle, like stem elongation and seed germination (Gupta and Chakrabarty, 2013). It was shown to affect xylem formation and plant lignification in various systems, causing upregulation in expression of lignin biosynthesis genes (Biemelt et al., 2004). Gibberellins exist as bioactive $\left(\mathrm{GA}_{1}, \mathrm{GA}_{3}, \mathrm{GA}_{4}\right.$, and $\left.\mathrm{GA}_{7}\right)$ and inactive forms (intermediates, precursors, and catabolites), the level of bioactive GAs being maintained by feedback and feedforward regulation of GA metabolism/biosynthesis and deactivation/degradation pathways (Hedden and Phillips, 2000; Olszewski et al., 2002). Gibberellin biosynthesis is regulated by ent-kaurene oxidase (KO), GA 20-oxidase (GA20ox), and GA 3-oxidase (GA3ox) genes and degradation is governed by a family of GA 2-oxidase isoforms (GA2ox) (Hedden and Phillips, 2000). The GA signaling pathway starts by binding of GA to its receptor, GA Insensitive Dwarf1 (GID1), which enhances an interaction between GID1 and DELLA that causes DELLA degradation and de-repression of the pathway (Sun, 2011). Another important player in GA regulation is gibberellic acid insensitive (GAI), being a repressor of GA responses (Peng et al., 1997).

Storage-root initiation involves proliferation of vascular cambial cells and starch accumulation (Firon et al., 2013; Ravi et al., 2014). In this context, it is of interest to highlight class I knotted 1-like (KNOX) genes, pointed out previously in different plant systems (Arabidopsis, poplar, and sweetpotato) as regulators of plant meristems, including cambial cells (Schrader et al., 2004; Scofield and Murray, 2006; Tanaka et al., 2008). Several KNOX gene sequences were previously identified by us to be upregulated in initiating sweetpotato SRs (Firon et al., 2013), including two Arabidopsis BREVIPEDICELLUS (BP) orthologues.
Interestingly, it was found that BP can regulate lignin biosynthesis. Overexpression of $B P$ was found to cause decreased lignification and $b p$ mutants exhibited elevated lignin levels (Mele et al., 2003). The possibility of binding of BP to lignin biosynthesis genes promoters was demonstrated (Mele et al., 2003). Another link was demonstrated between the $B P$ gene and GA, showing that BP may negatively regulate GA (Bolduc and Hake, 2009). In tobacco, overexpression of a KNOTTED-type protein caused decreased expression of a GA biosynthesis gene (Tanaka-Ueguchi et al., 1998). Hay et al. (2002) suggested that "repression of GA activity by KNOX transcription factors is a key component of meristem function.” During sweetpotato SR formation, vascular cambial cells develop into starch-accumulating parenchyma cells, exhibiting upregulated expression of genes involved in starch biosynthesis (Firon et al., 2013). Such genes include phosphoglucomutase (PGM), ADP glucose pyrophosphorylase (AGPase), granule-bound starch synthase (GBSS), and starch phosphorylase (SP) (Geigenberger, 2011).

In the present study, in order to better characterize the complex events that take place during the change of the sweetpotato AR into a SR, we looked into the effect of exogenous application of $\mathrm{GA}_{3}$ on root development and root lignin accumulation, together with vascular system- and xylem-development, starch accumulation, transcript levels of genes that regulate all these processes as well as the number of SRs formed. The results show that $\mathrm{GA}_{3}$ application influenced sweetpotato plant development by increasing stem elongation, caused a significant increase in levels of root bioactive GAs, decreased the number of ARs as well as the number and length of LRs, and reduced significantly the number of SRs. In addition, application of $\mathrm{GA}_{3}$ influenced root xylem development, caused increased lignin deposition, and decreased starch accumulation. The effect of $\mathrm{GA}_{3}$ application on starch accumulation was apparent as early as two weeks after planting. In accordance with these developmental effects, $\mathrm{GA}_{3}$ application was found to cause upregulated expression levels of sweetpotato orthologues of vascular development regulators (IbNA075, IbVND7, and IbSND2) and of lignin biosynthesis genes (IbPAL, IbC4H,Ib4CL,IbCCoAOMT, and IbCAD) and downregulation in expression levels of KNOX (IbKN2 and IbKN3) and starch biosynthesis (IbAGPase and IbGBSS) genes. These results point to GA, and potentially KNOX genes, as important regulators of root xylem development and lignification, on one hand, and formation of starch-accumulating cells, on the other hand, regulating SR formation and yield.

\section{MATERIALS AND METHODS}

\section{Plant Material, Growth Conditions, $\mathrm{GA}_{3}$, and Paclobutrazol Treatments}

Virus-tested sweetpotato stem cuttings were obtained from plants of the "Georgia Jet" cultivar, grown commercially in the Hasharon region, Israel. Stem cuttings with three nodes (nodes number 10 to 12 from the plant apex) were used for the study as described previously (Ma et al., 2015). Before planting, leaves of node 12 were removed and cuttings (node 12) were dipped separately into either water ("control"), a solution of gibberellic acid 3 ("GA,"; 
$50 \mathrm{ppm}$ diluted in water before use, following calibration of GA concentrations in the range of 10 to $1000 \mathrm{ppm}$, for getting an obvious, but not drastic, effect on plant development) or an inhibitor of GA synthesis, paclobutrazol ("PB"; 5 ppm in water, following calibration in the range of 1 to $20 \mathrm{ppm}$ ) (Wang et al., 1986), for $18 \mathrm{~h}$ in room temperature.

Thereafter, cuttings were planted into PVC pots $(10 \mathrm{~cm}$ diameter, $30 \mathrm{~cm}$ tall) prefilled with washed sand, by putting one node (node 12) in the soil. Subsequently, pots were transferred to a greenhouse at the Volcani Center, Rishon LeZion, Israel. The experiment was conducted during April 2017. Greenhouse temperature was maintained at $25 / 20^{\circ} \mathrm{C} \pm 3$ day/night temperatures under natural conditions, with no supplemental light. Minimum 16 cuttings were planted for each treatment group and each sampling time. A total of three treatments were used, as detailed below, and the plants were randomly arranged in one greenhouse. Plants were irrigated with $100 \mathrm{~mL}$ of either water (half field capacity; "control" treatment), an aqueous solution of 50 ppm $\mathrm{GA}_{3}$, or 5 ppm $\mathrm{PB}$ (“GA" and "PB" treatments, respectively) on every third day, until two weeks (2W) after planting. Thereafter plants were irrigated with a low $\mathrm{N}$ fertilizer solution (100 mg/L of 20: 20: $20 \mathrm{~N}$ : P: K; Haifa Chemicals, Israel), twice a week, until the end of the experiment.

\section{Plant Development Analyses}

For following the effect of $\mathrm{GA}_{3}$ and $\mathrm{PB}$ treatments on plant development, lateral stem length (originated from node 10) was measured at 3 weeks $(3 \mathrm{~W}), 4 \mathrm{~W}$, and $5 \mathrm{~W}$ after planting, using 16 plants (biological replicates) (Supplementary Figure S1). For looking into the effect of $\mathrm{GA}_{3}$ and $\mathrm{PB}$ on sweetpotato root development, the whole root system (originated from node 12) was sampled at $1 \mathrm{~W}, 2 \mathrm{~W}$, and $5 \mathrm{~W}$ after planting from each of the three treatment groups, using four plants per treatment out of the 16 planted plants (Supplementary Figure S1). These time points were chosen to represent (i) the phase in root development during which a developmental decision will be made toward becoming either a storage-root or a lignified non-storage-root (the first 2 weeks after planting; (Villordon et al., 2009) and (ii) the time when SR formation is observed (5W).

\section{Root Image Acquisition and Root System Architecture Analysis}

The whole root system was sampled at $1 \mathrm{~W}, 2 \mathrm{~W}$, and $5 \mathrm{~W}$ after planting as indicated above and maintained in 30\% ethanol at $4^{\circ} \mathrm{C}$ until analyzed. For analysis, roots were floated in a waterfilled tray, and scanned by an optical scanner (Epson Expression 1600, Japan). Images were analyzed using the WinRHIZO software version 5b (Regent Instruments Inc., Quebec, Canada), and by ImageJ software [ImageJ 1.51a, NIH, USA, (Schneider et al., 2012)]. Measured root parameters included: average root system fresh weight (FW; using 16 plants), root system dry weight (DW; analyzed after $72 \mathrm{~h}$ incubation in an oven at $60^{\circ} \mathrm{C}$, using four plants), number of AR per plant (counted manually), AR cumulative length per plant (calculated by ImageJ software from scanned images of WinRHIZO), average number of LR per plant (calculated by, "total tips count obtained from WinRHIZO analysis" minus "AR number"), LR cumulative length per plant (calculated by "total root length obtained from WinRHIZO analysis" minus "AR length"), LR density (LR number divided by AR length), and root surface area (derived from WinRHIZO analysis).The five parameters, AR and LR numbers, AR and LR length, and LR density were measured at $1 \mathrm{~W}$ and $2 \mathrm{~W}$ after planting using four biological replicates (plants). Average root system FW and DW, root volume, and root surface area per plant were recorded at $5 \mathrm{~W}$ after planting using four biological replicates (plants). The measured values included all root types (AR, LR, and SR) present at the time of sampling.

\section{Storage-Root Parameters}

Storage-root number per plant was evaluated at $5 \mathrm{~W}$ after planting using 16 plants per treatment (control, 50 ppm $\mathrm{GA}_{3}$ and $5 \mathrm{ppm}$ $\mathrm{PB}$ ). Analyzed SR parameters included average diameter (sampled from four plants) and average FW (sampled from 16 plants). It should be noted that the same 12 plants, per each treatment and sampling date, were used for looking into root anatomy, quantifying root endogenous GA levels and starch levels, and for gene expression analysis (RNA extraction) as detailed below and described in Supplementary Figure S1. For root anatomy, samples were fixed in FAA solution $(1 \mathrm{~L})$ containing; $100 \mathrm{~mL}$ of $35 \%$ formaldehyde, $50 \mathrm{~mL}$ of glacial acetic acid, $520 \mathrm{~mL}$ of $96 \%$ ethanol, and $330 \mathrm{~mL}$ of $\mathrm{dH}_{2} \mathrm{O}$. Sampled roots for endogenous GA, starch, and gene expression analyses were plunged immediately into liquid nitrogen and stored at $-80^{\circ} \mathrm{C}$ until use.

\section{Quantification of Endogenous Gibberellins}

Endogenous GAs levels were determined in sweetpotato ARs, derived from 12 plants which were sampled at $2 \mathrm{~W}$ after planting, according to the established protocol (Kolachevskaya et al., 2017). Fine-homogenized lyophilized root samples (10 mg) were extracted with $1 \mathrm{~mL}$ of $80 \%$ acetonitrile with $5 \%$ formic acid and deuterium-labeled GA internal standards $\left[{ }^{2} \mathrm{H}_{2}\right] \mathrm{GA}_{1}$, $\left[{ }^{2} \mathrm{H}_{2}\right] \mathrm{GA}_{3},\left[{ }^{2} \mathrm{H}_{2}\right] \mathrm{GA}_{4},\left[{ }^{2} \mathrm{H}_{2}\right] \mathrm{GA}_{7}$, and $\left[{ }^{2} \mathrm{H}_{2}\right] \mathrm{GA}_{20}$ (10 pmol of each compound). In the first step, samples were sonicated (5 min), rotated for $12 \mathrm{~h}\left(\right.$ at $4^{\circ} \mathrm{C}$ ), and centrifuged for $10 \mathrm{~min}$ at 17,000 rpm (at $4^{\circ} \mathrm{C}$ ). Supernatant was collected and kept at $-20^{\circ} \mathrm{C}$. The remained pellet was re-extracted with $1 \mathrm{~mL}$ of the extraction solvent without adding internal standards, sonicated, rotated for $1 \mathrm{~h}$ at $4^{\circ} \mathrm{C}$, and centrifuged for $10 \mathrm{~min}$ at $17,000 \mathrm{rpm}\left(\right.$ at $4^{\circ} \mathrm{C}$ ). Combined supernatants were dried in a Speed-Vac concentrator (Savant SC210A, Thermo, US), reconstituted by $5 \%$ of $\mathrm{NH}_{4} \mathrm{OH}$ (v/v) and loaded on Oasis ${ }^{\circledR}$ MAX column $(6 \mathrm{cc} / 150 \mathrm{mg}$, Waters Co., Milford, MA, USA). Before loading samples, the column was activated with $100 \% \mathrm{MeOH}$, washed with $\mathrm{mQ}$ water, and equilibrated with $5 \%$ of $\mathrm{NH}_{4} \mathrm{OH}$. Compounds were eluted with $0.2 \mathrm{M}$ formic acid in acetonitrile and the eluate was dried in vacuo. Thereafter, samples were reconstituted in $60 \mu \mathrm{L}$ of initial mobile phase $10 \mathrm{mM}$ formic acid: $\mathrm{MeOH}$ (80: 20, v/v), filtered through micro spin filters $0.2 \mu \mathrm{m}$ (Thermo Fisher Scientific, USA) and injected onto reversed-phase UPLC CSH C18 column (100 x 2.1 $\mathrm{mm}, 1.7 \mu \mathrm{m}$ ) of Acquity UPLC ${ }^{\mathrm{TM}}$ I-Class Core System (Waters, 
USA). GAs were separated isocratically at $80 \%$ of $10 \mathrm{mM}$ formic acid/water (A, v/v) and $20 \%$ of methanol (B) at a flow rate of $0.35 \mathrm{~mL} / \mathrm{min}$ for $1 \mathrm{~min}$, followed by consecutive linear gradient to 70 and $90 \%$ of B over 9 min. Column was thermostated at $50^{\circ} \mathrm{C}$. The effluent was introduced into electrospray ion source of Xevo ${ }^{\circledR}$ TQ-S triple quadrupole mass spectrometer (Waters MS Technologies, Manchester, UK), having the capillary voltage of $3 \mathrm{kV}$. The source block/desolvation temperature was adjusted to $120^{\circ} \mathrm{C} / 550^{\circ} \mathrm{C}$, and desolvation gas flow rate was maintained by $650 \mathrm{~L} \mathrm{~h}^{-1}$. Compounds were quantified by multiple ion monitoring mode (MRM) as described (Kolachevskaya et al., 2017). Data were processed using MassLynx ${ }^{\mathrm{TM}}$ software with TargetLynx ${ }^{\mathrm{TM}}$ program (version 4.1, Waters, USA).

\section{Analysis of Starch Levels}

Starch level was determined in ARs (sampled at $2 \mathrm{~W}$ and $5 \mathrm{~W}$ after planting) and in SRs (sampled at 5W) following the protocol of (MacRae (1971) with minor modifications. Powdered samples (250 mg), obtained following grinding in liquid $\mathrm{N}_{2}$, were treated with $6 \mathrm{ml}$ of $80 \%$ ethanol and incubated at $70^{\circ} \mathrm{C}$ for $45 \mathrm{~min}$. Following incubation, ethanol was discarded, fresh $80 \%$ ethanol was added and samples were incubated, as described above, this step being repeated twice. Finally, samples containing fresh $6 \mathrm{ml}$ of $80 \%$ ethanol were incubated at $70^{\circ} \mathrm{C}$ for $20 \mathrm{~min}$. After incubation, ethanol was discarded and tubes containing ethanol-insoluble sugar (starch) were kept in an oven at $60^{\circ} \mathrm{C}$ for drying overnight. Thereafter, $6 \mathrm{ml}$ of $\mathrm{dH}_{2} \mathrm{O}$ was added to the dried samples and were autoclaved at $121^{\circ} \mathrm{C}$ for $60 \mathrm{~min}$. Subsequently, samples were cooled down to room temperature and $4 \mathrm{ml}$ of working solution,

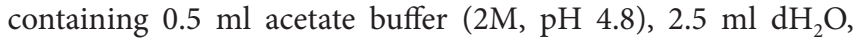
and $1 \mathrm{ml}$ of amyloglucosidase $(10 \mathrm{mg} / \mathrm{ml})$, was added to each sample. Tubes were covered with aluminum foil and kept for overnight shaking at $55^{\circ} \mathrm{C}$ in a water bath. Following overnight incubation, $250 \mu \mathrm{l}$ of sample solution was transferred into a 1.5 ml eppendorf tube, adding $250 \mu \mathrm{l}$ of $\mathrm{dH}_{2} \mathrm{O}$ and $500 \mu \mathrm{l}$ of Sumner reagent. Tubes were covered with aluminum foil and boiled in hot water for $5 \mathrm{~min}$ to follow the change in color from yellow to orange. Tubes were allowed to cool down at room temperature and measurements were done at $550 \mathrm{~nm}$ in a spectrophotometer (Pharmacia Biotech, USA). A glucose solution (0.04\%) was used for generating a standard curve.

\section{Histochemical Analysis and Autofluorescence Imaging}

Roots were sampled from six to eight plants from each treatment group ("control," 50 ppm "GA," and 5 ppm "PB") at $1 \mathrm{~W}, 2 \mathrm{~W}$, and $5 \mathrm{~W}$ after planting (5W samples were divided into lignified non-SR/ AR and SR). Samples stored in FAA solution (as mentioned above) were dehydrated using ethanol dilution series, followed by embedding in paraffin wax (Ruzin, 1999). Sectioning was done by a microtome (Leica RM2245, Leica Biosystems, Nussloch, Germany) and $15 \mu \mathrm{m}$ thick sections were prepared. Following sectioning, root sections were deparaffinized in a histoclear solution, rehydrated with ethanol dilution series, and used further for histochemical staining and autofluorescence imaging. Histochemical staining was done by either, safranin-fast green or Phloroglucinol-HCl ( $\mathrm{Ph}-\mathrm{HCl}$ or Weisner) staining to observe the root vascular system and lignin deposition (phloroglucinol is a good indicator of general cinnamaldehydes), respectively. For safranin-fast green staining, deparaffinized samples were stained for $2 \mathrm{~h}$ in safranin-O (1\%) with counter staining for $10 \mathrm{~s}$ in fast green $(0.5 \%)$. Phloroglucinol- $\mathrm{HCl}$ staining was done according to an established protocol by Mitra and Loque (2014), where deparaffinized samples were stained with a freshly prepared $\mathrm{Ph}-\mathrm{HCl}$ stain and observed immediately under the microscope ( $\mathrm{Ph}-\mathrm{HCl}$ causes sample deterioration). Microscopic examination of sections was done by a light microscope (Leica, Germany) and images were digitally captured by a Nikon DS-Fil digital camera. Autofluorescence imaging of unstained, deparaffinized sections was done by Confocal microscopy (Donaldson and Knox, 2012). Autofluorescence was detected under UV excitation at $365 \mathrm{~nm}$ with a PMT detector in range of 415-490 $\mathrm{nm}$. Using $\mathrm{UV}$ is a simple method to visualize lignin and other aromatic molecules. All microscopic observations and image acquisitions were performed by a Leica SP8 laser scanning microscope (Leica, Wetzlar, Germany), equipped with a solid-state laser with 405 nm light, HC PL APO CS 10x/0.40 objective (Leica, Wetzlar, Germany), and Leica Application Suite X software (LASX, Leica, Wetzlar, Germany).

Root vascular parameters were determined from images captured after histochemical analysis. Total xylem vessel number was calculated by counting the number of protoxylem, metaxylem and secondary xylem elements in root sections. Moreover, area covered by xylem elements (vessels and fibers) and total root area were calculated using the imagej software (Imagej 1.51a, NIH, USA, (Schneider et al., 2012), and percent root area occupied by xylem vessels (protoxylem, metaxylem, and secondary xylem) and xylem fibers was determined.

\section{RNA Extraction and Gene Expression Analysis}

Total RNA was extracted from sweetpotato ARs at $1 \mathrm{~W}, 2 \mathrm{~W}$, and $5 \mathrm{~W}$ after planting (5W sampled roots included both, ARs and SRs), using RNeasy Plant Mini Kit (Qiagen, Germany). The integrity and quantity of RNA was examined by gel-electrophoresis and nanodrop (ND 1000, Thermo Scientific, USA), respectively. DNA contamination from RNA samples was removed using TURBO DNA-free ${ }^{\mathrm{TM}}$ kit (Ambion, Life Technology, USA). The cDNA was prepared using the Verso cDNA Synthesis Kit according to the manufacturer's protocol (Thermo Scientific, Lithuania), and was used for further analyses.

Gene expression analysis was performed by quantitative reverse transcriptase-PCR (qRT-PCR) using a $10 \mu \mathrm{L}$ reaction volume containing CDNA, forward and reverse primers, and ABsolute Blue qPCR SYBR Green ROX Mix (Thermo Scientific, Lithuania). Reactions were performed in a Rotor Gene 6000 Real-Time PCR System (Corbett Life Science, Australia) using 40 cycles of $10 \mathrm{~s}$ at $95^{\circ} \mathrm{C}, 15 \mathrm{~s}$ at $60^{\circ} \mathrm{C}$, and $20 \mathrm{~s}$ at $72^{\circ} \mathrm{C}$. Results were analyzed by Rotor gene software, and relative expression levels of targeted genes were calculated by the $2^{-\Delta \mathrm{Ct}}$ method. The selection of a reference gene was done according to Park et al. (2012). Total 10 candidate reference genes, including 
beta actin, ribosomal protein L, glyceraldehyde-3- phosphate dehydrogenase, cyclophilin, a-tubulin, ADP-ribosylation factor, histone $\mathrm{H} 2 \mathrm{~B}$, ubiquitin extension protein, cytochrome c oxidase subunit Vc, and phospholipase Dla were tested. Among these, phospholipase Dla was found to be most suitable, having stable gene expression, and was used for data normalization in our experiments.

Primers were designed using Primer3Plus ${ }^{1}$ and are listed in Supplementary Table S1.

\section{Sequence and Statistical Analyses}

BLAST and tBLASTx were used to compare sequences of candidate sweetpotato contigs/genes of GA biosynthesis and signaling, lignin biosynthesis, and upstream regulators, class I knotted 1-like and starch metabolism, derived from our published database (Firon et al., 2013) with Arabidopsis ${ }^{2}$ and $\mathrm{NCBI}^{3}$ databases. For NAC-domain-containing sequences, in order to identify potential up-regulators of lignin and xylem development, homology against PlantTFDB database ${ }^{4}$ was performed. Selected sweetpotato NAC genes were further investigated by motif search $^{5}$, and phylogenetic (using MEGA with neighbor-joining method and 1000 bootstrap replicates) analyses for their similarly to Arabidopsis genes, in order to identify potential orthologues of NAC075, VND, and SND genes (Supplementary Figure S2).

Data statistical analyses were performed using student's t-test at $P \leq 0.05$, using JMP 5.0.1a statistical software (SAS Institute Inc., NC, United States).

\section{RESULTS}

\section{Exogenous Application of $\mathrm{GA}_{3}$ Influences Sweetpotato Stem Growth and Root System Architecture}

The effect of exogenous application of $\mathrm{GA}_{3}$ and of the GA biosynthesis inhibitor $\mathrm{PB}$ was tested on stem growth and on root characteristics. The experimental setup and conditions used are detailed in Supplementary Figure S1. The lateral stem length measured at $3 \mathrm{~W}, 4 \mathrm{~W}$, and $5 \mathrm{~W}$ after planting was found to change significantly by $\mathrm{GA}_{3}$ and $\mathrm{PB}$ treatments as compared to control (Figure 1). The stem was 9.7-, 8.1-, and 6.5-fold longer following $\mathrm{GA}_{3}$ treatment, while $\mathrm{PB}$ treatment caused stem shortening compared to control by 2.3-, 4.0-, and 5.3-fold, at $3 \mathrm{~W}$, $4 \mathrm{~W}$, and $5 \mathrm{~W}$, respectively. Thus, $\mathrm{GA}_{3}$ and $\mathrm{PB}$ showed antagonistic effects causing elongated or stunted stem growth, respectively, throughout sweetpotato plant development.

We have previously demonstrated that the initial stages of AR development are critical in determining SR set in sweetpotato (Villordon et al., 2009). For this reason, the effect of exogenous application of $\mathrm{GA}_{3}$ and $\mathrm{PB}$ on root characteristics was studied

\footnotetext{
${ }^{1}$ http://www.bioinformatics.nl/cgi-bin/primer3plus/primer3plus.cgi

${ }^{2}$ https://www.arabidopsis.org

${ }^{3}$ https://www.ncbi.nlm.nih.gov

${ }^{4} \mathrm{http}: / /$ planttfdb.cbi.pku.edu.cn

${ }^{5}$ https://www.genome.jp/tools/motif/
}

during the first two weeks after planting. During this period, stem cuttings were treated with the hormone or inhibitor solution as described in Materials and Methods. The results of root system FW and DW at $1 \mathrm{~W}$ and $2 \mathrm{~W}$ after planting are presented in Supplementary Figure S3, showing a significant reduction in both parameters by both $\mathrm{GA}_{3}$ and $\mathrm{PB}$ at $2 \mathrm{~W}$ (2.0- and 3.4-fold as well as 1.7- and 2.1-fold, for $\mathrm{GA}_{3}$ and $\mathrm{PB}$ respectively). Moreover, significant reduction in AR number, AR cumulative length, LR number, and LR cumulative length per plant was observed at $2 \mathrm{~W}$ after planting following both, $\mathrm{GA}_{3}$ and $\mathrm{PB}$ treatments (Figures 2A, B, C, and D, respectively). For example, 1.9- and 2.9- as well as 1.7and 2.5-fold reduction in $\mathrm{AR}$ number and length was observed at 2W, with $\mathrm{GA}_{3}$ and $\mathrm{PB}$ treatments, respectively (Figures 2A, B). While, 2.3- and 4.9- as well as 3.0- and 5.5-fold reduction in LR number and LR cumulative length, was detected following $\mathrm{GA}_{3}$ and PB treatments, respectively (Figures 2C, D). Adventitious root and LR number was reduced already at $1 \mathrm{~W}$ after planting by $\mathrm{GA}_{3}$ and not by $\mathrm{PB}$ (Figures $2 \mathrm{~A}, \mathrm{C}$, respectively). Lateral root density increased more than 3 -fold at $2 \mathrm{~W}$ as compared to $1 \mathrm{~W}$, under all tested conditions, and no significant differences were apparent following $\mathrm{GA}_{3}$ or $\mathrm{PB}$ applications (Figure 2E). As for root surface area, a significant decrease (more than 3 -fold) was recorded for both $\mathrm{GA}_{3}$ and $\mathrm{PB}$ treatments at $2 \mathrm{~W}$ after planting (Figure $2 \mathrm{~F}$ ).

\section{Exogenous Application of $\mathrm{GA}_{3}$ Affects Storage-Root Formation and Characteristics}

Root system architecture parameters, including root system FW, DW, volume, and surface area, were further recorded at $5 \mathrm{~W}$ after planting, when SR formation was already detected. The results show significant reduction by both $\mathrm{GA}_{3}$ and $\mathrm{PB}$ treatments in all tested parameters (Supplementary Figure S4). Both $\mathrm{GA}_{3}$ and $\mathrm{PB}$

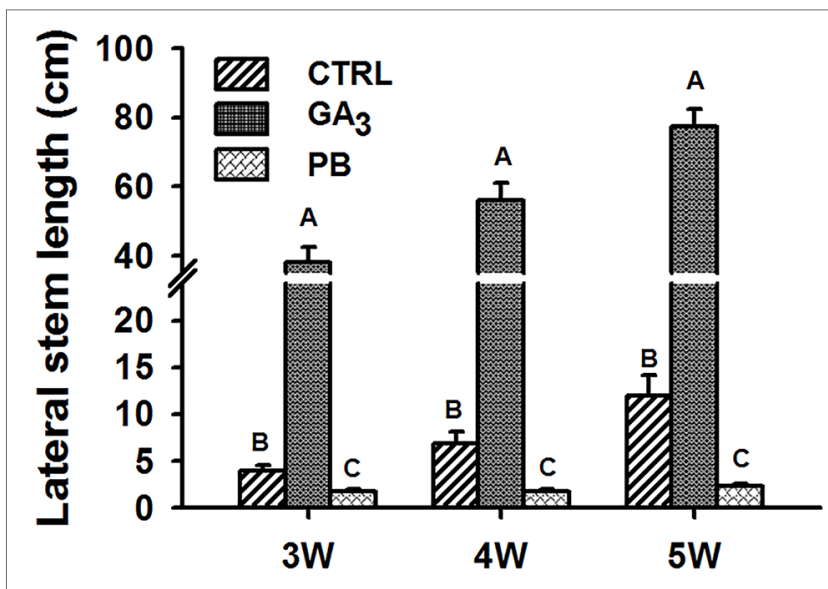

FIGURE 1 | Effect of GA $_{3}$ application on sweetpotato "Georgia Jet" stem growth. Lateral stem length was recorded at three, four, and five weeks (3W, 4W, and 5W, respectively) after planting. Bars represent mean of 16 independent biological replicates (plants) \pm SE. Significance analysis was performed by using student's t-test $(P \leq 0.05)$, where unlike letters represent significant differences between treatments within a sampling group. CTRL, Control (treated with water); $\mathrm{GA}_{3}$, application of 50 ppm gibberellic acid 3 for two weeks; PB, application of 5 ppm paclobutrazol for two weeks. 

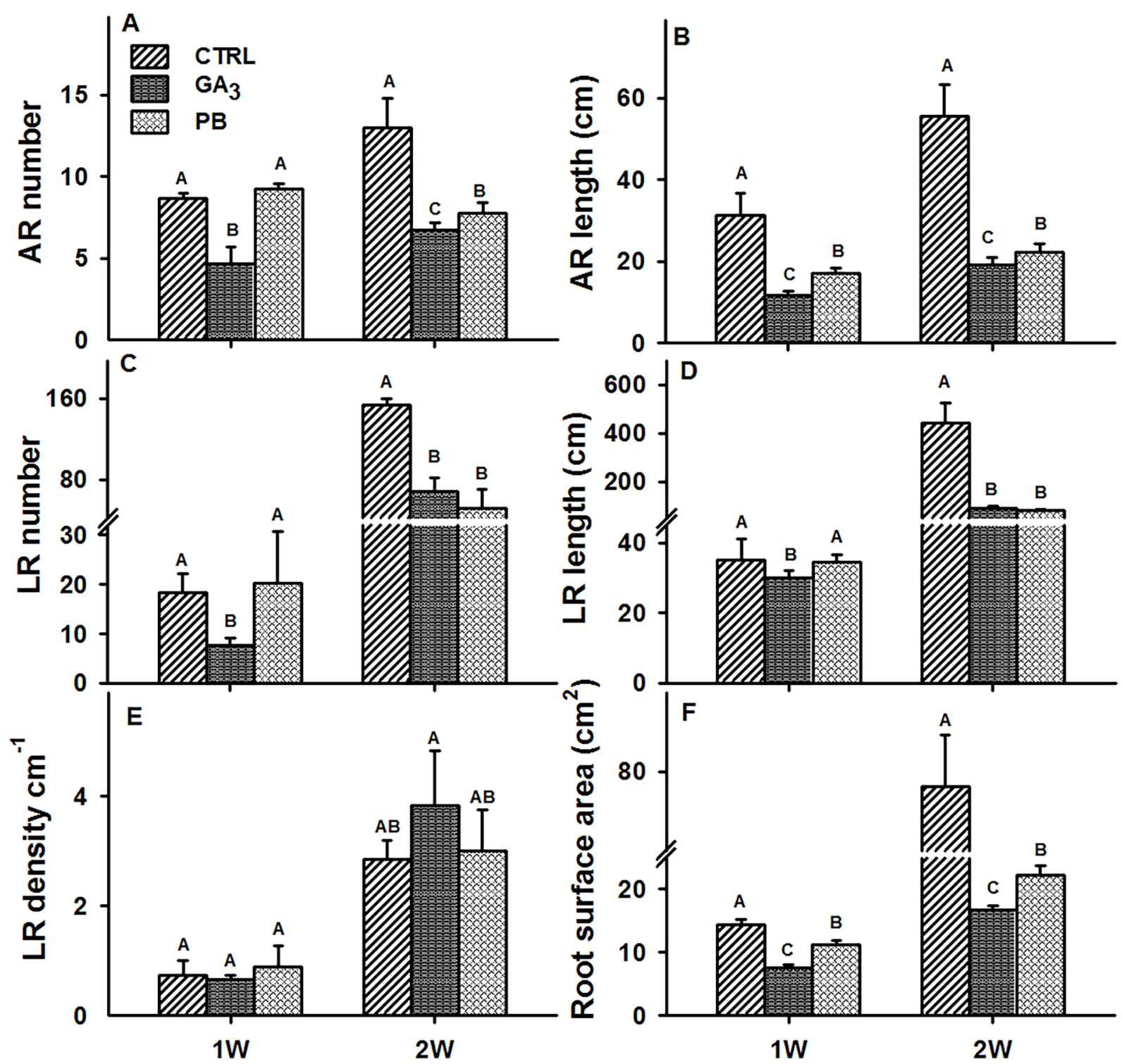

FIGURE 2 | Effect of $\mathrm{GA}_{3}$ application on sweetpotato "Georgia Jet" root system architecture parameters. The parameters included adventitious root (AR) number per plant (A), AR cumulative length per plant (B), lateral root (LR) number per plant (C), LR cumulative length per plant (D), LR density per AR (E), and root surface area per plant (F), determined at one and two weeks (1W and 2W, respectively) after planting. Bars represent mean of four independent biological replicates (plants) \pm SE. Significance analysis was performed by using student's t-test $(P \leq 0.05)$, where unlike letters represent significant differences between treatments within a sampling group. CTRL, Control (treated with water); $\mathrm{GA}_{3}$, application of 50 ppm gibberellic acid 3 for two weeks; PB, application of 5 ppm paclobutrazol for two weeks.

treatment affected SR formation as well as SR average diameter and weight, with $\mathrm{GA}_{3}$ causing a more pronounced effect. The reduction was apparent in SR number (3.3- and 2.5-fold), SR diameter (2.1- and 1.2-fold), and SR FW (2.1- and 1.2-fold), in response to $\mathrm{GA}_{3}$ and $\mathrm{PB}$ application, respectively (Figure 3).

\section{Changes in Endogenous GA Levels in the Sweetpotato Root System Following Exogenous $\mathrm{GA}_{3}$ Treatment}

In order to examine the effect of exogenous $\mathrm{GA}_{3}$ or $\mathrm{PB}$ application on endogenous levels of GAs in sweetpotato roots, the $2 \mathrm{~W}$ root samples from control and treated $\left(\mathrm{GA}_{3}\right.$ or $\left.\mathrm{PB}\right)$ plants were collected to quantify changes in GA levels, and results for major bioactive as well as inactive GAs, are presented in Figure 4. GA treatment caused a significant elevation (more than 7.0-fold) in the levels of all tested bioactive GAs $\left(\mathrm{GA}_{1}, \mathrm{GA}_{3}, \mathrm{GA}_{4}\right.$, and $\mathrm{GA}_{7}$ ) and 17.2-fold for the measured inactive form $\mathrm{GA}_{20}$ (direct precursor of $\mathrm{GA}_{1}$ and precursor of $\mathrm{GA}_{3}$ ). Exogenous application of $\mathrm{PB}$, caused the opposite effect, reducing the levels of all tested bioactive GAs by more than 2-fold. The content of $\mathrm{GA}_{3}$ was relatively high in all root samples, reaching values of 10,000 ; 70,000; and 4,000 $\mathrm{ng} \mathrm{g}^{-1} \mathrm{DW}$ in control, $\mathrm{GA}_{3}-$ and PB-treated roots, respectively. 


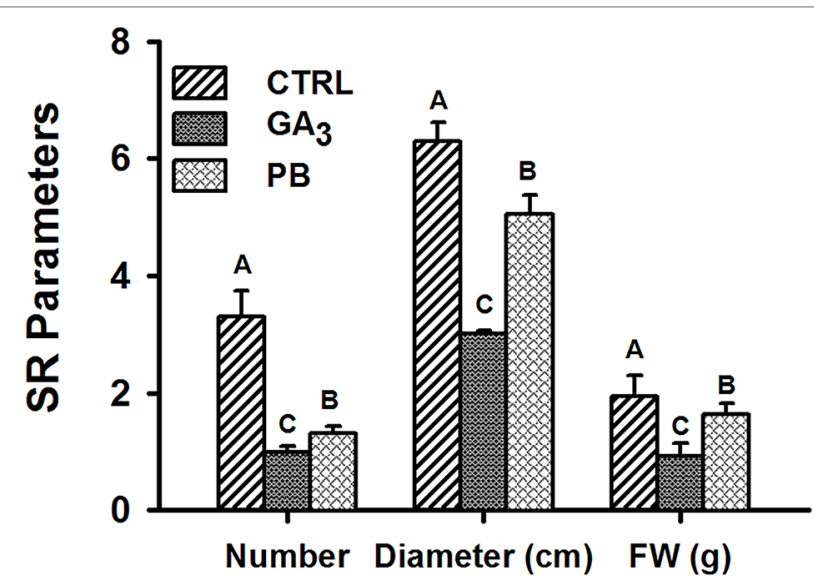

FIGURE 3 | Effect of $\mathrm{GA}_{3}$ application on sweetpotato "Georgia Jet" storageroot characteristics. Storage-root (SR) number, average diameter and fresh weight (FW) per plant were recorded at five weeks (5W) after planting. Bars represent mean of 16 (for SR number and fresh weight; FW) or four (for SR diameter) independent biological replicates (plants) \pm SE. Significance analysis was performed by using student's t-test $(P \leq 0.05)$, where unlike letters represent significant differences between treatments within a sampling group. CTRL, Control (treated with water); $\mathrm{GA}_{3}$, application of $50 \mathrm{ppm}$ gibberellic acid 3 for two weeks; PB, application of 5 ppm paclobutrazol for two weeks.

\section{Exogenous Application of $\mathrm{GA}_{3}$ Influences Sweetpotato Root Xylem Development and Lignification}

In view of previous studies in other systems showing that $\mathrm{GA}_{3}$ promotes xylem development and vascular lignification (Guo et al., 2015; Wang et al., 2017), it was interesting to study its effect on sweetpotato root anatomy and on SR characteristics. Roots were thus harvested at the phase of SR initiation (1W and 2W) and at the time when SRs were already formed (5W) and analyzed for AR anatomical structure and xylem development. Analyses of the $5 \mathrm{~W}$ samples were done using two root types; $\mathrm{SR}$ as well as AR that did not develop into a SR (sampled from the same plants). Cross-sections of ARs at $1 \mathrm{~W}$ and $2 \mathrm{~W}$ after planting show that root anatomy was influenced by both $\mathrm{GA}_{3}$ and $\mathrm{PB}$ treatments, exhibiting higher number of xylem vessels (Figure 5A). At this early phase of root development most xylem vessels were primary xylem (protoxylem and metaxylem) and a significant increase in protoxylem and metaxylem number at $1 \mathrm{~W}$, by both $\mathrm{GA}_{3}$ and $\mathrm{PB}$ treatments, was observed (Figure 5B). At $2 \mathrm{~W}$ after planting, both $\mathrm{GA}_{3}$ - and PB-treated roots exhibited significantly higher number of metaxylem cells compared to control, while the highest number of protoxylem cells was recorded following $\mathrm{PB}$ treatment (Figure 5B). $\mathrm{GA}_{3}$ treatment was found to promote secondary xylem formation, as evident in $2 \mathrm{~W}$ and $5 \mathrm{~W}$ cross-sections of ARs (Figure 5B). At 5W, those ARs that did not develop into SRs exhibited reduced number of protoxylem and metaxylem vessels and elevated number of secondary xylem vessels, following $\mathrm{GA}_{3}$ treatment as compared to control (Figure 5B). The 5W, $\mathrm{GA}_{3}$ treated AR sections exhibited formation of large secondary xylem vessels and a high number of xylem fibers (Figure 5A), manifested by the relative large area of the root section occupied by xylem vessels and fibers (Figure 5C). This phenomenon was already apparent at $1 \mathrm{~W}$ and $2 \mathrm{~W}$ after planting (Figure 5C). Paclobutrazol application, as opposed to $\mathrm{GA}_{3}$, did not induce fiber formation (Figure 5C). Cross-sections of SRs formed at 5W of development did not exhibit major differences between treatments except for formation of an irregular vascular cambium ring in $\mathrm{GA}_{3}$-treated plants (Supplementary Figure S5).

In order to follow the effect of gibberellin on lignification, we have used auto-fluorescence imaging (being a nonspecific tool indicative of lignin and various phenolics (Donaldson and Knox, 2012) as well as phloroglucinol staining (indicative of the 4-O-linked hydroxycinnamyl aldehyde structures in lignins) (Pomar et al., 2002) and results are presented in Figure 6. The results indicate higher lignification of root cross-sections induced by $\mathrm{GA}_{3}$ as well as $\mathrm{PB}$ treatments, as visualized by both auto-fluorescence and phloroglucinol staining (Figures 6A, B, respectively). Highest lignification/lignified area was evident in $2 \mathrm{~W}$ and $5 \mathrm{~W}$ samples following $\mathrm{GA}_{3}$ treatment. It should be noted that $\mathrm{GA}_{3}$ and $\mathrm{PB}$ treatments were stopped at $2 \mathrm{~W}$ after planting, while their effect was obvious during the treatment period and several weeks afterwards. At $5 \mathrm{~W}$, the lignified area in $\mathrm{GA}_{3}$-treated

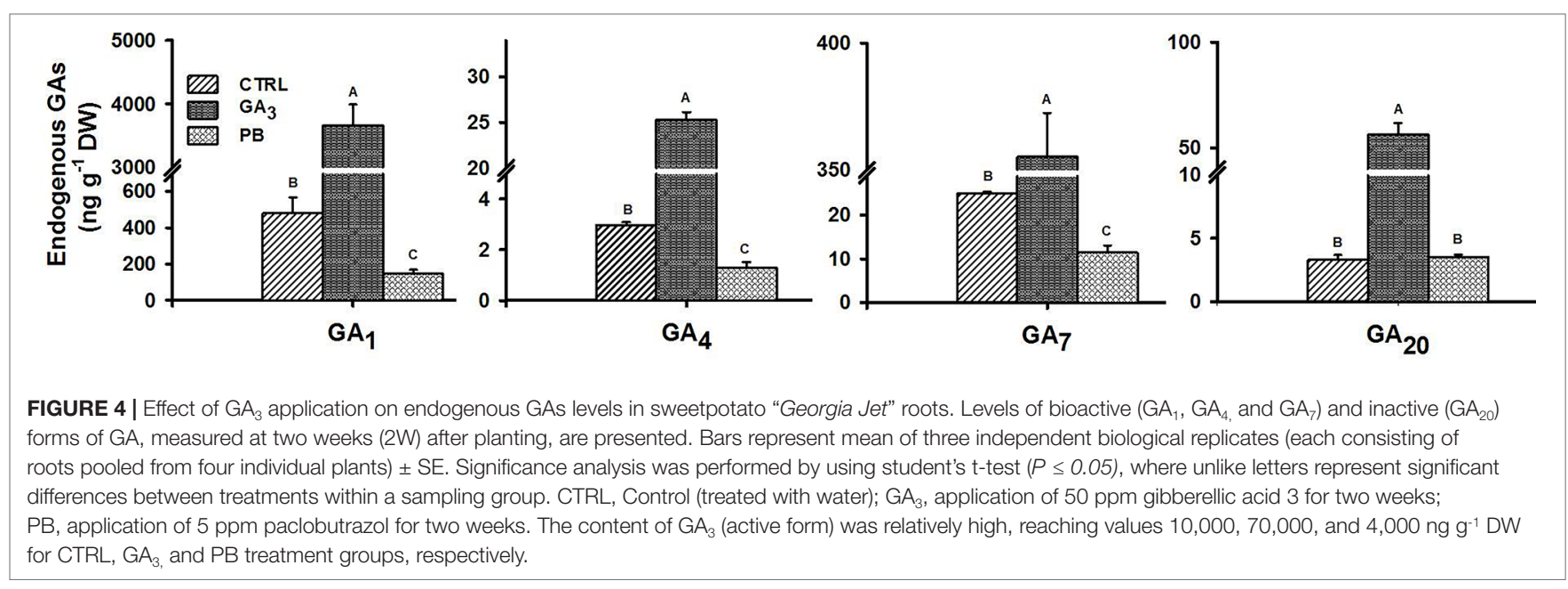




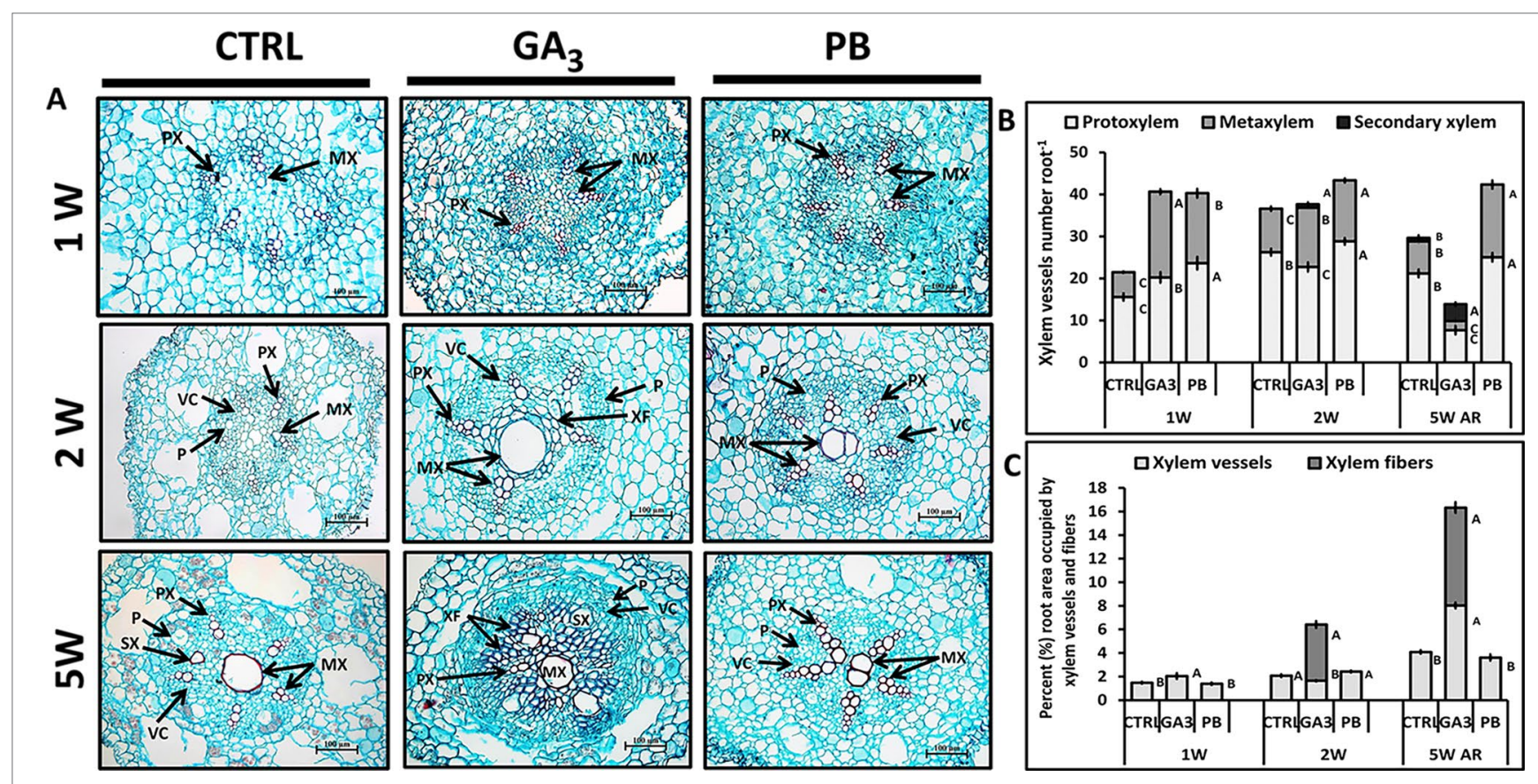

FIGURE 5 | Effect of $\mathrm{GA}_{3}$ application on sweetpotato "Georgia Jet" root anatomy and xylem development. (A) Representative cross-sections of adventitious roots (AR) sampled at one, two, and five weeks ( $1 \mathrm{~W}, 2 \mathrm{~W}$, and $5 \mathrm{~W}$, respectively) after planting. Sections were stained with safranin and fast green, and represent six to eight roots sampled from individual plants. Some of the vessels are lignified and stained red. (B) Xylem vessels number per AR, including protoxylem, metaxylem and secondary xylem sampled at 1W, 2W, and 5W. (C) Percent (\%) root area occupied by xylem vessels (protoxylem, metaxylem and secondary xylem) and xylem fibers. Bars (B, C) represent mean of six to eight independent biological replicates (plants) \pm SE. Significance analysis was performed by using student's t-test $(P \leq 0.05)$, where unlike letters represent significant differences between treatments within a sampling group. CTRL, Control (treated with water); $G A_{3}$, application of 50 ppm gibberellic acid 3 for two weeks; PB, application of 5 ppm paclobutrazol for two weeks. PX, protoxylem; MX, metaxylem; SX, secondary xylem; XF, xylem fibers; VC, vascular cambium; P, phloem. Scale bar $=100 \mu \mathrm{m}$.

roots was represented mainly by fibers, while in PB-treated roots it was represented by proto- and meta-xylem cells.

\section{Exogenous Application of $\mathrm{GA}_{3}$ Affects Starch Accumulation in Sweetpotato Roots}

Since starch accumulation is an important indication for formation of a SR, we investigated starch content at $2 \mathrm{~W}$ (in ARs) and 5W (in ARs and SRs) after planting in nontreated and treated $\left(\mathrm{GA}_{3}-\right.$ and $\mathrm{PB}$-treated) plant roots (Figure $7 \mathrm{~A}$ ). $\mathrm{GA}_{3}$ was found to significantly reduce starch content in both $2 \mathrm{~W}$ and $5 \mathrm{~W}$ AR samples. Interestingly, $\mathrm{GA}_{3}$ treatment showed a significant reducing effect on starch accumulation also in roots that developed into SRs. Paclobutrazol application did not show an effect on starch accumulation in ARs at either $2 \mathrm{~W}$ or $5 \mathrm{~W}$ after planting, while causing reduction in starch levels accumulating in SRs. Furthermore, $\mathrm{GA}_{3}$ and $\mathrm{PB}$ treatments caused reduced starch granule density in SRs as seen in cross-sections (Figure 7B).

\section{Exogenous Application of $\mathrm{GA}_{3}$ Influences the Expression Pattern of Genes Related to Gibberellin Biosynthesis and Regulation}

We identified sweetpotato orthologues for Arabidopsis genes involved in GA regulation, vascular development, lignin biosynthesis, meristem regulation, and starch biosynthesis, using the respective gene sequences/contigs derived by us previously by sequencing the "Georgia Jet" root transcriptome (Firon et al., 2013). The list of all sweetpotato contigs together with the respective Arabidopsis genes is presented in Table 1. The expression pattern of the following GA-related genes was followed during root development at $1 \mathrm{~W}, 2 \mathrm{~W}$, and $5 \mathrm{~W}$ : GA biosynthesis genes, ent-kaurene oxidase (IbKO), GA20-oxidase (IbGA20ox), and GA3-oxidase4 (IbGA3ox4) (Figure 8A); GA catabolizing genes, GA2-oxidase (IbGA2ox1, IbGA2ox3, and $I b G A 20 x 8$ ) (Figure 8B), and genes involved in GA signaling and regulation, GIBBERELLIN INSENSITIVE DWARF1 (IbGID1) and GIBBERELLIC ACID INSENSITIVE (IbGAI) (Figure $\mathbf{8 C}$ ). The results show a significant increase in $I b K O$ expression following $\mathrm{GA}_{3}$ application, exhibiting 4.1- and 3.6-fold increased transcript level at $2 \mathrm{~W}$ and $5 \mathrm{~W}$ ARs, respectively, compared with control (Figure 8A). Similarly, IbGA20ox expression increased significantly by $\mathrm{GA}_{3}$ in $\mathrm{ARs}$ harvested at $1 \mathrm{~W}, 2 \mathrm{~W}$, and $5 \mathrm{~W}$, while IbGA3ox4 expression increased mainly in 5W ARs (Figure 8A). The expression of the GA receptor gene, IbGID1, was also strongly upregulated by $\mathrm{GA}_{3}$ application, 1.8- and 13.4-fold at $1 \mathrm{~W}$ and $5 \mathrm{~W}$ ARs, respectively, while genes involved in GA catabolism (IbGA2ox1 and IbGA2ox3) were down-regulated (Figure 8B). The expression of yet another GA2-oxidase (IbGA2ox8) was however upregulated by $\mathrm{GA}_{3}$ (1.7-fold in $2 \mathrm{~W}$ and $5 \mathrm{~W}$ ARs). Application of $\mathrm{PB}$ caused an opposite effect compared to $\mathrm{GA}_{3}$, 


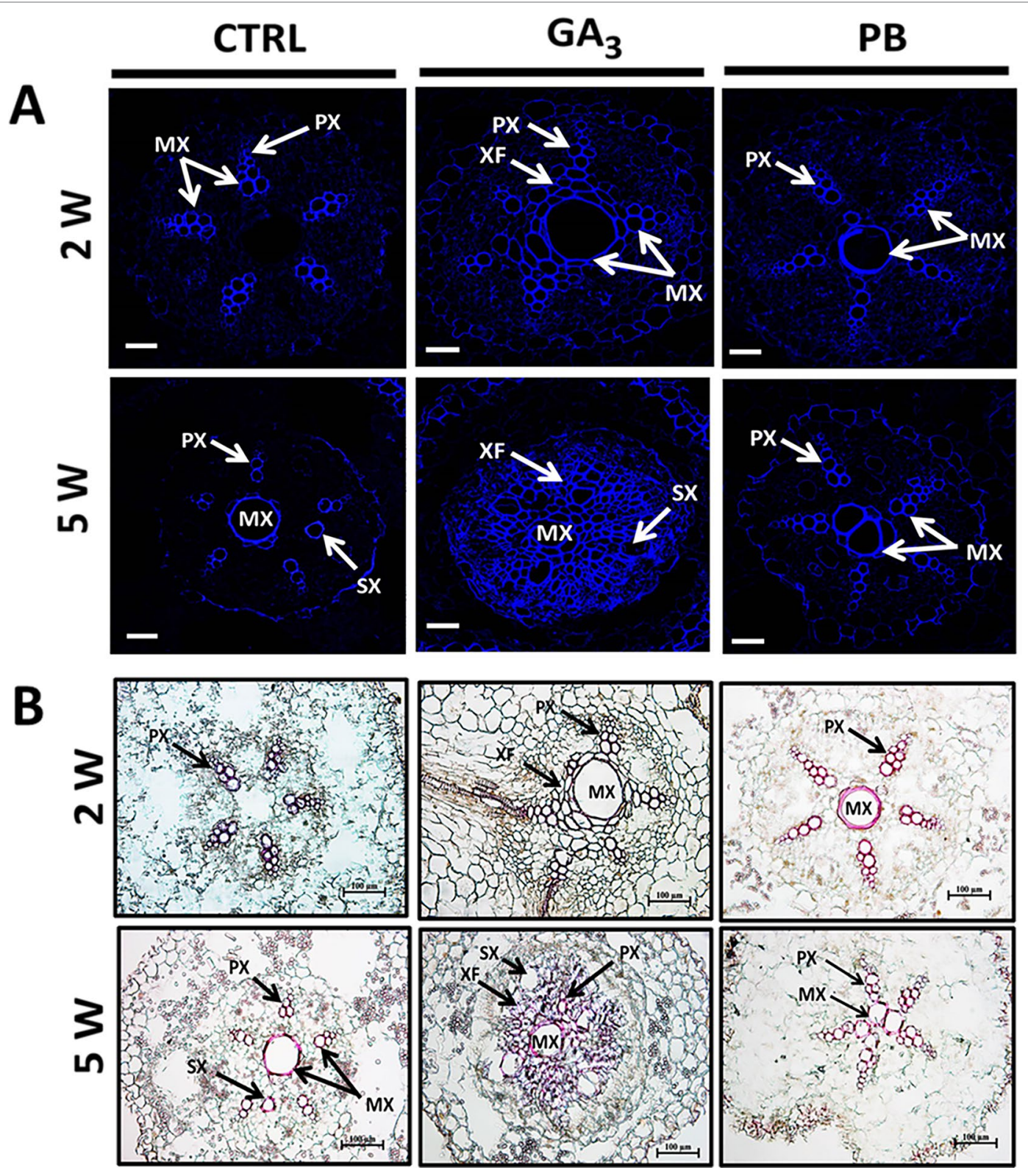

FIGURE 6 | Effect of $\mathrm{GA}_{3}$ application on sweetpotato "Georgia Jet" root lignin accumulation as viewed by auto-fluorescence imaging (A) and phloroglucinol-HCl staining (B). Representative cross-sections of adventitious roots sampled at two and five weeks (2W and $5 \mathrm{~W}$, respectively) after planting. Use of autofluorescence imaging (a nonspecific tool indicative of lignin and various phenolics) specifying secondary-wall material deposition in xylem showing blue fluorescence under UV excitation at $365 \mathrm{~nm}$, points to lignin accumulation in xylem elements including proto-, meta-, and secondary xylem, and xylem fibers (A). Phloroglucinol$\mathrm{HCl}$ staining (being more specific and indicative of 4-O-linked hydroxycinnamyl aldehyde structures in lignins) stained lignified cells wall, where lignin deposition appears as pink-red color in proto-, meta-, and secondary xylem, and xylem fibers (B). Presented sections represent six to eight roots sampled from individual plants. CTRL, Control (treated with water); $\mathrm{GA}_{3}$, application of 50 ppm gibberellic acid 3 for two weeks; PB, application of 5 ppm paclobutrazol for two weeks. PX, protoxylem; MX, metaxylem; SX, secondary xylem; XF, xylem fibers. Scale bar $=50 \mu \mathrm{m}$ (A) and $100 \mu \mathrm{m}$ (B)

downregulating expression of two GA biosynthesis genes (IbGA20ox and IbGA3ox4) as well as downregulating IbGA2ox8 (evident in $2 \mathrm{~W}$ and $5 \mathrm{~W}$ ARs), while causing upregulation of IbGA2ox1 (evident in 5W ARs). Expression of IbGID1 was maintained similar to control (Figure 8C). The negative regulator of GA, IbGAI, showed variable responses to $\mathrm{GA}_{3}$ and
$\mathrm{PB}$, being opposite in $5 \mathrm{~W}$ ARs (reduced expression by $\mathrm{GA}_{3}$ and upregulation by $\mathrm{PB}$ ). Comparing between 5W ARs and SRs, similar expression patterns were observed for IbGA2ox8 and $I b G I D 1$ following $\mathrm{GA}_{3}$ and $\mathrm{PB}$ treatments, while expression of $I b G A 20 o x, I b G A 2 o x 1$, and $I b G A 2 o x 3$ was found to stay similar in SRs across treatments. 
A

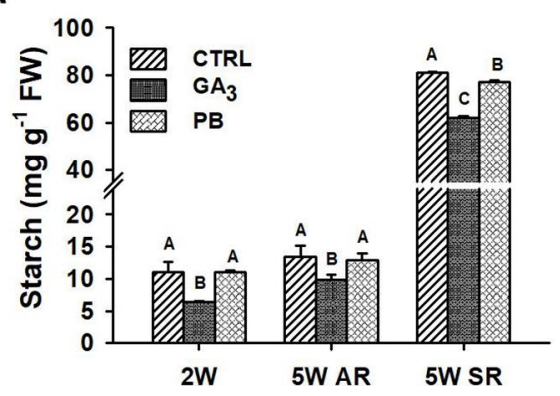

B CTRL

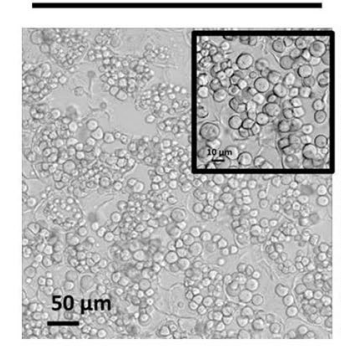

$\mathrm{GA}_{3}$

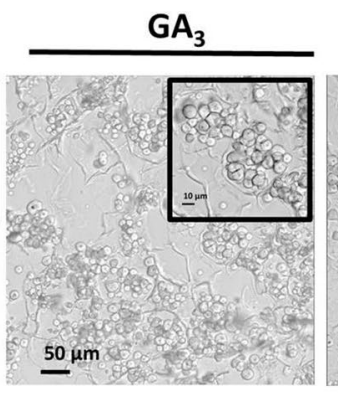

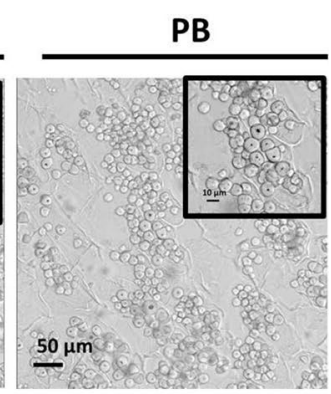

FIGURE 7 | Effect of $\mathrm{GA}_{3}$ application on starch level (A), and starch granules accumulation (B) in sweetpotato "Georgia Jet" roots. Starch level was quantified in roots collected at two and five weeks ( $2 \mathrm{~W}$ and $5 \mathrm{~W}$, respectively) after planting. At $5 \mathrm{~W}$, both adventitious roots (AR) that did not develop into storage-root (SR), and SR were analyzed. Bars in (A) represent mean of three independent biological replicates (each representing roots pooled from four plants) \pm SE. Significance analysis was performed by using student's t-test $(P \leq 0.05)$, where unlike letters represent significant differences between treatments within a group. Cross sections of SR collected at $5 \mathrm{~W}$ of development, representing six independent biological replicates (plants), are given in (B) as viewed under a confocal microscope focusing on starch granules. Scale bar = $50 \mu \mathrm{m}$ and $10 \mu \mathrm{m}$ (in inset). Control (treated with water); $\mathrm{GA}_{3}$, application of 50 ppm gibberellic acid 3 for two weeks; PB, application of 5 ppm paclobutrazol for two weeks.

\section{Expression of Genes Involved in Regulation of Vascular Development and Lignin Biosynthesis in Response to $\mathrm{GA}_{3}$ Application}

To look for genes involved in the regulation of root xylem development and vascular lignification following $\mathrm{GA}_{3}$ application, we identified the following sweetpotato orthologues of the respective Arabidopsis genes: IbNAC075 (upstream regulator of VND7) (Endo et al., 2015), IbVND7 (involved in xylem vessel differentiation) (Yamaguchi et al., 2008), IbSND2 (regulator of genes involved in secondary wall development) (Hussey et al., 2011), IbXND1 (negative regulator of xylem formation) (Tang et al., 2018), IbVNI2 (transcriptional repressor of VND7) (Yamaguchi et al., 2010), and IbVNI2-like (Table 1) and their transcript profiles were investigated (Figure 9). The expression of all tested positive regulators (Figure 9A) was induced by $\mathrm{GA}_{3}$ treatment as evident in ARs sampled at $5 \mathrm{~W}$ after planting, while expression of IbNAC075 was upregulated earlier, already at $2 \mathrm{~W}$ (Figure 9A). The expression of the negative regulators, IbXND1 and $I b V N I 2$, was, however, downregulated by $\mathrm{GA}_{3}$ (5.2- and 1.7fold, respectively, in 5W ARs) (Figure 9B). Expression of IbVNI2like was upregulated (2.5-fold) by $\mathrm{GA}_{3}$ application when tested at $5 \mathrm{~W}$ after planting. Application of $\mathrm{PB}$ exhibited an opposite effect as compared to $\mathrm{GA}_{3}$ on expression of most tested genes as evident in the $5 \mathrm{~W}$ samples (showing down- and up-regulated expression of IbNAC075 and IbXND1, respectively; Figure 9).

Lignin biosynthesis starts with deamination of phenylalanine by PAL, followed by a series of reactions involving $\mathrm{C} 4 \mathrm{H}, 4 \mathrm{CL}$, HCT, CCoAOMT, and CAD (Kao et al., 2002; Raes et al., 2003). All tested sweetpotato lignin biosynthesis genes, exhibited significantly elevated transcript levels following application of $\mathrm{GA}_{3}$ (Figure 10). This upregulation was evident in ARs sampled at $2 \mathrm{~W}$ and $5 \mathrm{~W}$ after planting and, in the case of $I b P A L$ and $I b 4 C L$, already at $1 \mathrm{~W}$ after planting. This gene expression pattern parallels the elevated lignification observed in tissue sections (Figure 6). The expression of all lignin-biosynthesis genes (except IbHCT), following $\mathrm{PB}$ treatment was, however, significantly lower as compared to roots of $\mathrm{GA}_{3}$-treated plants (as seen in the $2 \mathrm{~W}$ and 5W AR samples; Figure 10).

In the context of lignification, it was of high interest to test the transcript profiles of two class I knotted 1-like transcription factors, orthologues of the Arabidopsis BP gene, IbKN2 and IbKN3, following $\mathrm{GA}_{3}$ treatment. The $B P$ gene was previously shown to regulate lignin accumulation and lignin biosynthesis genes in Arabidopsis (Mele et al., 2003). Expression of both IbKN2 and $I b K N 3$ followed a similar pattern, exhibiting significantly downregulated transcript levels following $\mathrm{GA}_{3}$ treatment (Figure 11). The inhibitory effect of $\mathrm{GA}_{3}$ on $I b K N 2 / 3$ expression was evident also in the sampled SRs. Paclobutrazol did not show a pronounced effect on the expression of these genes at $2 \mathrm{~W}$, although at $5 \mathrm{~W}$, when tested in ARs, it caused reduced expression of $I b K N 3$ and exhibited no effect on IbKN2 (Figure 11). It is worth mentioning that $B P$ orthologues were previously indicated as markers of cambial cells and were shown to regulate development and maintenance of the shoot apical meristem in various plants (Vollbrecht et al., 2000; Schrader et al., 2004).

\section{Expression of Genes Involved in Starch Biosynthesis in Response to $\mathrm{GA}_{3}$ Application}

The following six sweetpotato genes, known to be involved in carbohydrate metabolism and starch biosynthesis were studied for their expression behavior following $\mathrm{GA}_{3}$ and $\mathrm{PB}$ treatments: Sucrose synthase (IbSuSy), phosphoglucomutase (IbPGM), ADP-glucose pyrophosphorylase small and large subunits (IbAGPa1 and $I b A G P b 1 A$, respectively), granule-bound starch synthase (IbGBSS), and starch phosphorylase (IbSP) (Figure 12). Expression of all tested genes, except $I b P G M$, was reduced by $\mathrm{GA}_{3}$ application. Expression of IbSuSy and AGPb1A was downregulated 2.2 - and 4.0 -fold, respectively, as early as $2 \mathrm{~W}$, and 8.7- and 24.7-fold, respectively, in 5W ARs. In addition, $\mathrm{GA}_{3}$ application caused down-regulation in expression of IbGBSS and 
TABLE 1 | Sweetpotato (Ipomoea batata) Georgia Jet orthologues/genes investigated in our study.

\begin{tabular}{|c|c|c|c|c|c|c|}
\hline $\begin{array}{l}\text { Ipomoea } \\
\text { batata contigs }\end{array}$ & $\begin{array}{l}\text { Ipomoea batata } \\
\text { gene }\end{array}$ & Source/NCBI accessions & $\begin{array}{l}\text { Arabidopsis } \\
\text { homolog }\end{array}$ & $\begin{array}{l}\text { Arabidopsis gene } \\
\text { name }\end{array}$ & Gene function & Gene Family \\
\hline \multicolumn{7}{|c|}{ Gibberellin biosynthesis and signaling/regulation } \\
\hline S_PBL_c17751 & Kurene oxidase (IbKO) & Firon et al., 2013 & AT5G25900 & $\begin{array}{l}\text { Ent-Kaurene oxidase } \\
1(K O)\end{array}$ & $\begin{array}{l}\text { Gibberellin } \\
\text { biosynthesis }\end{array}$ & Various \\
\hline S_PBL_c36353 & $\begin{array}{l}\text { Gibberellin } \\
\text { 20-dioxygenase } \\
\text { (IbGA2Oox) }\end{array}$ & Firon et al., 2013 & AT4G25420 & $\begin{array}{l}\text { Gibberellin } 20 \text { oxidase } \\
1(\text { GA2Oox } 1)\end{array}$ & $\begin{array}{l}\text { Gibberellin } \\
\text { biosynthesis }\end{array}$ & \\
\hline S_PBL_c51845 & $\begin{array}{l}\text { Gibberellin 3-beta- } \\
\text { dioxygenase } 4 \\
(\text { IbGA3ox4) }\end{array}$ & Firon et al., 2013 & AT1G80330 & $\begin{array}{l}\text { Gibberellin } 3 \text { oxidase } \\
4(G A 30 \times 4)\end{array}$ & $\begin{array}{l}\text { Gibberellin } \\
\text { biosynthesis }\end{array}$ & \\
\hline S_PBL_c23111 & $\begin{array}{l}\text { Gibberellin 2-oxidase } 1 \\
(I b G A 20 \times 1)\end{array}$ & Firon et al., 2013 & AT1G78440 & $\begin{array}{l}\text { Gibberellin 2-oxidase } \\
1 \text { (GA2ox1) }\end{array}$ & $\begin{array}{l}\text { Catalyzing bioactive } \\
\text { GAs to inactive forms }\end{array}$ & \\
\hline S_PBL_c32 & $\begin{array}{l}\text { Gibberellin 2-oxidase } 3 \\
\text { (IbGA2ox3) }\end{array}$ & Firon et al., 2013 & AT1G78440 & $\begin{array}{l}\text { Gibberellin 2-oxidase } \\
1(\text { GA2ox1) }\end{array}$ & $\begin{array}{l}\text { Catalyzing bioactive } \\
\text { GAs to inactive forms }\end{array}$ & \\
\hline S_PBL_c13427 & $\begin{array}{l}\text { Gibberellin 2-oxidase8 } \\
\text { (IbGA2ox8) }\end{array}$ & Firon et al., 2013 & AT5G58660 & $\begin{array}{l}\text { 2-oxoglutarate (2OG) } \\
\text { Fe(II)-dependent } \\
\text { oxygenase }\end{array}$ & $\begin{array}{l}\text { Catalyzing bioactive } \\
\text { GAs to inactive forms }\end{array}$ & \\
\hline S_PBL_c19593 & $\begin{array}{l}\text { Gibberellin insensitive } \\
\text { dwarf1 (IbGID1) }\end{array}$ & Firon et al., 2013 & AT3G63010 & $\begin{array}{l}\text { GA insensitive } \\
\text { dwarf1b (GID1B) }\end{array}$ & Gibberellin receptor & \\
\hline S_PBL_c1873 & $\begin{array}{l}\text { GA-insensitive (/bGAI/ } \\
\text { RGA2)/DELLA protein }\end{array}$ & Firon et al., 2013 & AT1G14920 & $\begin{array}{l}\text { Gibberellic acid } \\
\text { insensitive (GAl) }\end{array}$ & $\begin{array}{l}\text { Repressor of } \\
\text { gibberellin responses }\end{array}$ & \\
\hline \multicolumn{7}{|c|}{ Regulators of vascular development } \\
\hline S_PBL_c36855 & $\begin{array}{l}\text { VASCULAR RELATED } \\
\text { NAC-DOMAIN } \\
\text { PROTEIN } 075 \\
\text { (IbNACO75) }\end{array}$ & Firon et al., 2013 & AT4G29230 & $\begin{array}{l}\text { NAC DOMAIN } \\
\text { CONTAINING } \\
\text { PROTEIN 75, } \\
\text { (NAC075) }\end{array}$ & $\begin{array}{l}\text { Secondary wall } \\
\text { biosynthesis in xylem } \\
\text { vessels. }\end{array}$ & $\begin{array}{l}\text { NAC- } \\
\text { DOMAIN } \\
\text { PROTEIN }\end{array}$ \\
\hline S_PBL_c32341 & $\begin{array}{l}\text { VASCULAR RELATED } \\
\text { NAC-DOMAIN } \\
\text { PROTEIN } 7 \text { (IbVND7) }\end{array}$ & Firon et al., 2013 & AT1G71930 & $\begin{array}{l}\text { VASCULAR RELATED } \\
\text { NAC-DOMAIN } \\
\text { PROTEIN } 7 \text { (VND7) }\end{array}$ & $\begin{array}{l}\text { Xylem vessel } \\
\text { differentiation }\end{array}$ & \\
\hline S_PBL_c24252 & $\begin{array}{l}\text { SECONDARY WALL- } \\
\text { ASSOCIATED NAC } \\
\text { DOMAIN } 2 \text { (IbSND2) }\end{array}$ & Firon et al., 2013 & AT4G28500 & $\begin{array}{l}\text { SECONDARY WALL- } \\
\text { ASSOCIATED NAC } \\
\text { DOMAIN PROTEIN 2, } \\
\text { (SND2) }\end{array}$ & $\begin{array}{l}\text { Secondary wall } \\
\text { biosynthesis in xylem } \\
\text { fibers }\end{array}$ & \\
\hline S_PBL_C504 & $\begin{array}{l}\text { XYLEM NAC } \\
\text { DOMAIN1 (IbXND1) }\end{array}$ & Firon et al., 2013 & AT5G64530 & $\begin{array}{l}\text { XYLEM NAC DOMAIN } \\
1 \text { (XND1) }\end{array}$ & $\begin{array}{l}\text { Negative regulator } \\
\text { of xylem vessel } \\
\text { differentiation } \\
\text { and secondary wall } \\
\text { thickening }\end{array}$ & \\
\hline S_PBL_C4628 & $\begin{array}{l}\text { VND-INTERACTING2 } \\
\text { (IbVNI2) }\end{array}$ & Firon et al., 2013 & AT5G13180 & $\begin{array}{l}\text { NAC DOMAIN } \\
\text { CONTAINING } \\
\text { PROTEIN } 83 \\
\text { (NACO83), VND- } \\
\text { INTERACTING } 2 \\
\text { (VNI2) }\end{array}$ & $\begin{array}{l}\text { Negative regulator } \\
\text { of xylem vessel } \\
\text { differentiation } \\
\text { and secondary wall } \\
\text { thickening }\end{array}$ & \\
\hline S_PBL_c17476 & $\begin{array}{l}\text { VND-INTERACTING2 } \\
\text { like (IbVNI2-like) }\end{array}$ & Firon et al., 2013 & AT1G62700 & $\begin{array}{l}\text { NAC DOMAIN } \\
\text { CONTAINING } \\
\text { PROTEIN 83-like } \\
\text { (NAC083-like), VND- } \\
\text { INTERACTING } 2 \\
\text { (VNI2-like) }\end{array}$ & $\begin{array}{l}\text { Negative regulator } \\
\text { of xylem vessel } \\
\text { differentiation } \\
\text { and secondary wall } \\
\text { thickening }\end{array}$ & \\
\hline \multicolumn{7}{|c|}{ Lignin biosynthesis } \\
\hline S_PBL_C2312 & $\begin{array}{l}\text { Phenylalanine } \\
\text { ammonia lyase (IbPAL) }\end{array}$ & Firon et al., 2013 & AT2G37040 & $\begin{array}{l}\text { Phenylalanine } \\
\text { ammonia lyase } 1 \\
(P A L 1)\end{array}$ & Lignin biosynthesis & Various \\
\hline S_PBL_c7605 & $\begin{array}{l}\text { Cinnamate } \\
\text { 4-hydroxylase }(I b C 4 H)\end{array}$ & Firon et al., 2013; GQ373157 & AT2G30490 & $\begin{array}{l}\text { Cinnamate-4- } \\
\text { hydroxylase }(C 4 H)\end{array}$ & Lignin biosynthesis & \\
\hline S_PBL_c18044 & $\begin{array}{l}\text { 4-Coumarate-CoA } \\
\text { ligase (Ib4CL) }\end{array}$ & Firon et al., 2013 & AT1G51680 & $\begin{array}{l}\text { 4-Coumarate : Coa } \\
\text { ligase } 1(4 C L)\end{array}$ & Lignin biosynthesis & \\
\hline S_PBL_c17752 & $\begin{array}{l}\text { Hydroxycinnamoyl } \\
\text { transferase }(\mathrm{IbHCT})\end{array}$ & Firon et al., 2013; AB576768 & AT5G48930 & $\begin{array}{l}\text { Hydroxycinnamoyl } \\
\text { transferase }(H C T)\end{array}$ & Lignin biosynthesis & \\
\hline S_PBL_C2944 & $\begin{array}{l}\text { Caffeoyl-CoA-O- } \\
\text { methyltransferase } \\
(\text { IbCCOAOMT) }\end{array}$ & Firon et al., 2013; EU250002 & AT4G34050 & $\begin{array}{l}\text { Caffeoyl coenzyme a } \\
\text { o-methyltransferase } 1 \\
(\mathrm{CCOAOMT)}\end{array}$ & Lignin biosynthesis & \\
\hline
\end{tabular}


TABLE 1 | Continued

\begin{tabular}{|c|c|c|c|c|c|c|}
\hline $\begin{array}{l}\text { Ipomoea } \\
\text { batata contigs }\end{array}$ & $\begin{array}{l}\text { Ipomoea batata } \\
\text { gene }\end{array}$ & Source/NCBI accessions & $\begin{array}{l}\text { Arabidopsis } \\
\text { homolog }\end{array}$ & $\begin{array}{l}\text { Arabidopsis gene } \\
\text { name }\end{array}$ & Gene function & Gene Family \\
\hline S_PBL_Irc53688 & $\begin{array}{l}\text { Cinnamyl alcohol } \\
\text { dehydrogenase } \\
(I b C A D)\end{array}$ & Firon et al., 2013; GU380306 & AT4G39330 & $\begin{array}{l}\text { Cinnamyl Alcohol } \\
\text { Dehydrogenase }(C A D)\end{array}$ & Lignin biosynthesis & \\
\hline \multicolumn{7}{|c|}{ Class I knotted 1-like } \\
\hline S_PBL_c8137 & $\begin{array}{l}\text { Class I knotted1-like } \\
\text { homeobox (KNOX1) } \\
\text { (IbKN2) }\end{array}$ & Firon et al., 2013; AB283028 & AT4G08150 & $\begin{array}{l}\text { BREVIPEDICELLUS } \\
\text { (KNAT1) }\end{array}$ & $\begin{array}{l}\text { Meristematic } \\
\text { maintenance }\end{array}$ & KNOX1 \\
\hline S_PBL_c31412 & $\begin{array}{l}\text { Class I knotted1-like } \\
\text { homeobox (KNOX1) } \\
(\text { IbKN3) }\end{array}$ & Firon et al., 2013; AB283029 & AT4G08150 & $\begin{array}{l}\text { BREVIPEDICELLUS } \\
\text { (KNAT1) }\end{array}$ & $\begin{array}{l}\text { Meristematic } \\
\text { maintenance }\end{array}$ & \\
\hline \multicolumn{7}{|c|}{ Carbohydrate metabolism and starch biosynthesis } \\
\hline S_PBL_c543 & $\begin{array}{l}\text { Sucrose synthase } \\
\text { (IbSuSy) }\end{array}$ & Firon et al., 2013; EU908020 & AT3G43190 & $\begin{array}{l}\text { Sucrose synthase } 4 \\
\text { (SUS4) }\end{array}$ & Sucrose metabolism & Various \\
\hline S_PBL_C20112 & $\begin{array}{l}\text { Phosphoglucomutase } \\
\text { (IbPGM) }\end{array}$ & Firon et al., 2013 & AT1G70730 & $\begin{array}{l}\text { Phosphoglucomutase } \\
2 \text { (PGM2) }\end{array}$ & $\begin{array}{l}\text { Interconversion of } \\
\text { glucose 1-phosphate } \\
\text { and glucose } \\
6 \text {-phosphate }\end{array}$ & \\
\hline S_PBL_C18129 & $\begin{array}{l}\text { ADP-glucose } \\
\text { pyrophosphorylase } \\
\text { alpha subunit } \\
\text { (IbAGPa1) }\end{array}$ & $\begin{array}{l}\text { Firon et al., 2013; KJ365312, } \\
\text { JQ797696, Z79635, X83498, } \\
\text { Z46756, AY544766 }\end{array}$ & AT5G48300 & $\begin{array}{l}\text { ADP-glucose } \\
\text { pyrophosphorylase } \\
\text { small subunit }\end{array}$ & Starch biosynthesis & \\
\hline S_PBL_C54187 & $\begin{array}{l}\text { ADP-glucose } \\
\text { pyrophosphorylase } \\
\text { beta subunit } \\
(\text { IbAGPb1A) }\end{array}$ & $\begin{array}{l}\text { Firon et al., 2013; JQ797698, } \\
\text { JQ797692, AB271013, } \\
\text { AF068260, AJ249257, } \\
\text { AJ249256, AJ252316, } \\
\text { AJ245392, AB071976 }\end{array}$ & AT1G27680 & $\begin{array}{l}\text { ADP-glucose } \\
\text { pyrophosphorylase } \\
\text { large subnuit }\end{array}$ & Starch biosynthesis & \\
\hline S_PBL_c3042 & $\begin{array}{l}\text { Granule-bound starch } \\
\text { synthase (IbGBSS) }\end{array}$ & $\begin{array}{l}\text { Firon et al., 2013; } \\
\text { AB524722/23/24/25/26/27/28, } \\
\text { AB071604 }\end{array}$ & AT1G32900 & $\begin{array}{l}\text { Granule bound starch } \\
\text { synthase } 1 \text { (GBSS1) }\end{array}$ & Starch biosynthesis & \\
\hline S_PBL_c1370 & $\begin{array}{l}\text { Starch phosphorylase } \\
(I b S P)\end{array}$ & $\begin{array}{l}\text { Firon et al., 2013; L25626, } \\
\text { M64362 }\end{array}$ & AT3G29320 & $\begin{array}{l}\text { ALPHA-glucan } \\
\text { phosphorylase } 1 \\
(P H S 1)\end{array}$ & $\begin{array}{l}\text { Phosphorolytic } \\
\text { degradation of starch }\end{array}$ & \\
\hline
\end{tabular}

$\operatorname{IbSP}$ (2.1- and 2.6-fold, respectively, in 5W ARs). The inhibitory effect of $\mathrm{GA}_{3}$ on expression levels of all tested genes (except IbPGM) was evident also in SRs. Paclobutrazol treatment did not cause a significant change in expression in either of the tested carbohydrate metabolism genes at $2 \mathrm{~W}$ of development, while expression of $I b S u S y, I b A G P a 1$ and $I b A G P b 1 A$ was reduced when tested in 5W ARs (Figure 12).

\section{DISCUSSION}

\section{Root System Architecture During the First 2 Weeks of Root Development Is Linked to Transition of the Sweetpotato Adventitious Root Into a Storage-Root}

The aim of the current study was to gain an understanding of the key physiological and molecular events/mechanisms that mark the developmental transition of the sweetpotato AR into a storage organ. The work was based upon previous findings from our laboratory (in collaboration with the laboratories of A. Villordon and D. LaBonte) demonstrating that (i) the initial ARs that develop from stem-cutting possess the necessary requirements for forming SRs (Villordon et al., 2009); (ii) SR initiation phase spans the first two weeks after planting (Villordon et al., 2009). We made use of the plant hormone GA, shown previously to affect RSA (Gou et al., 2010) and lignification (Wang et al., 2017; Duan et al., 2019), in order to study its effect on sweetpotato root development, SR formation, lignin accumulation, and the expression levels of lignin-biosynthesis, and carbohydrate metabolism/starch-biosynthesis genes as well as potential upstream regulators. This enabled us to get an insight into what processes and genes are involved in SR initiation.

Exogenous application of $\mathrm{GA}_{3}$ to sweetpotato plants during the first two weeks of development caused elevated levels of bioactive and non-bioactive GAs in the roots together with an increase in the plant's stem length. Such an effect was previously reported in other systems like dandelion (Kim et al., 2009) and apple (Zhang et al., 2016). Increased levels of different GAs in response to $\mathrm{GA}_{3}$ application point to either conversion of $\mathrm{GA}_{3}$ to the other bioactive forms (by a yet unknown mechanism), downregulation of catabolism and/or possible upregulation of the GA biosynthesis pathway by a feedforward mechanism. Transcript levels of sweetpotato orthologues of the Arabidopsis GA biosynthesis genes IbKO,IbGA20ox, and IbGA3ox and the receptor $I b G I D 1$ were highly upregulated by $\mathrm{GA}_{3}$, while transcript levels of genes encoding enzymes of GA deactivation (IbGA2ox1 and IbGA2ox3) were found to be downregulated, matching the induced endogenous GAs levels observed in our study and pointing to the potential existence of a feedforward mechanism. However, contrary to our findings, GA treatment 

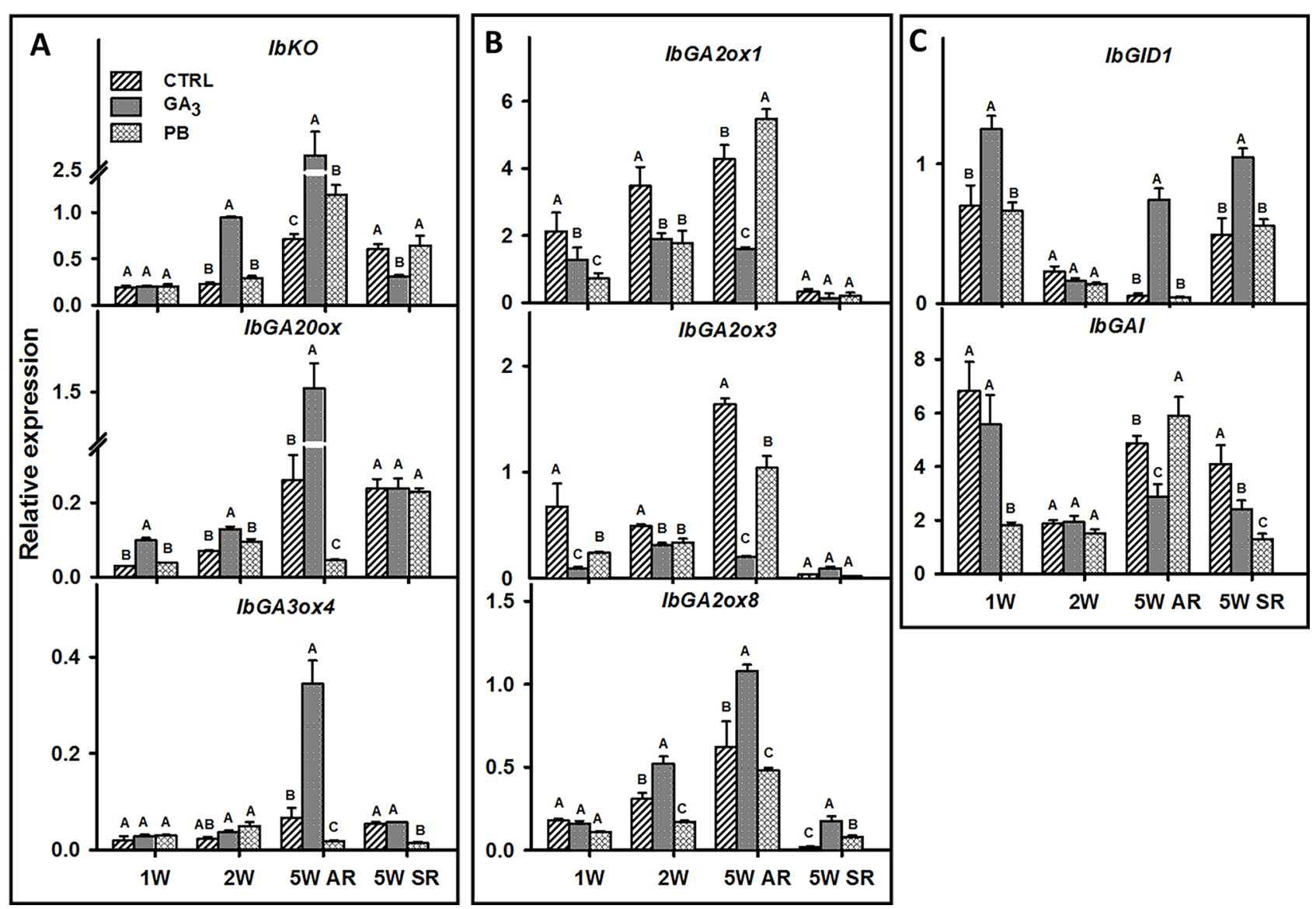

FIGURE 8 | The effect of $\mathrm{GA}_{3}$ application on expression profiles of sweetpotato "Georgia Jet" orthologs/genes involved in gibberellin biosynthesis (A), catabolism (B), and signaling/regulation (C) in adventitious roots (AR) and storage-roots (SR). Expression/transcript levels were measured at 1W, 2W, and 5W after planting for $\mathrm{AR}$ and at $5 \mathrm{~W}$ for SR, using qRT-PCR analyses, and values were normalized relative to the expression levels of phospholipase D1a. qRT-PCR data are mean ( \pm SE) of three independent biological replicates (each representing roots pooled from four plants). Significance analysis was performed by using student's t-test $(P \leq 0.05)$, where unlike letters represent significant differences between treatments within a group. Control (treated with water); GA 3 , application of 50 ppm gibberellic acid 3 for two weeks; PB, application of 5 ppm paclobutrazol for two weeks.

was previously shown to downregulate the expression of GA20ox and upregulate expression of GA2ox (Thomas et al., 1999), and expression of GA biosynthesis genes was found to be elevated in a GA-deficient background and to be downregulated after application of bioactive GAs (Thomas et al., 1999; Yamaguchi, 2008 and references therein). Additional experiments are thus required in order to better understand the regulation of GA homeostasis in this unique system of sweetpotato AR development. Another interesting issue that requires additional study is the potential cross-talk and transport of GAs between shoot and root. Paclobutrazol, that functions as an inhibitor of GA biosynthesis by inhibiting oxidation of ent-kaurene into ent-kaurenoic acid (Rademacher, 2000), caused, as expected, reduction in all tested root GAs levels accompanied by reduction in sweetpotato stem length.

Exogenous application of $\mathrm{GA}_{3}$ caused a significant reduction in most tested RSA parameters, measured during the first two weeks after planting (SR initiation phase). Inhibition of root growth by $\mathrm{GA}_{3}$ treatment was recorded in other systems like carrot (Wang et al., 2015b; Wang et al., 2017). These inhibitory effects of GA on sweetpotato LR development and RSA were linked with a significant reduction in SR formation (SR number) and SR characteristics (diameter and weight). Thus, $\mathrm{GA}_{3}$ application affected both, the capacity of ARs to become SRs, and the further development and "bulking" of the small number of SRs that were formed. These results point to root architecture attributes during the first two weeks of plant development as being important and as playing a role in the developmental transition of the AR into a SR. Indeed, Villordon and Clark (2014) and Villordon et al. (2014) stressed the importance of root architecture in root (sweetpotato, cassava) and tuber (potato) crop productivity. It was previously demonstrated that ARs that showed evidence for SR initiation had higher values for LR attributes such as LR number, length, and surface area (Villordon et al., 2012).

The effect of $\mathrm{PB}$ on most tested root system parameters and on SR production was similar to that of $\mathrm{GA}_{3}$ in spite of its antagonistic effect on endogenous root GA levels. These results may point to (i) involvement of other factors besides GA in the effect of PB application or (ii) need for a delicate control of GA levels (not too much and not too little) in 


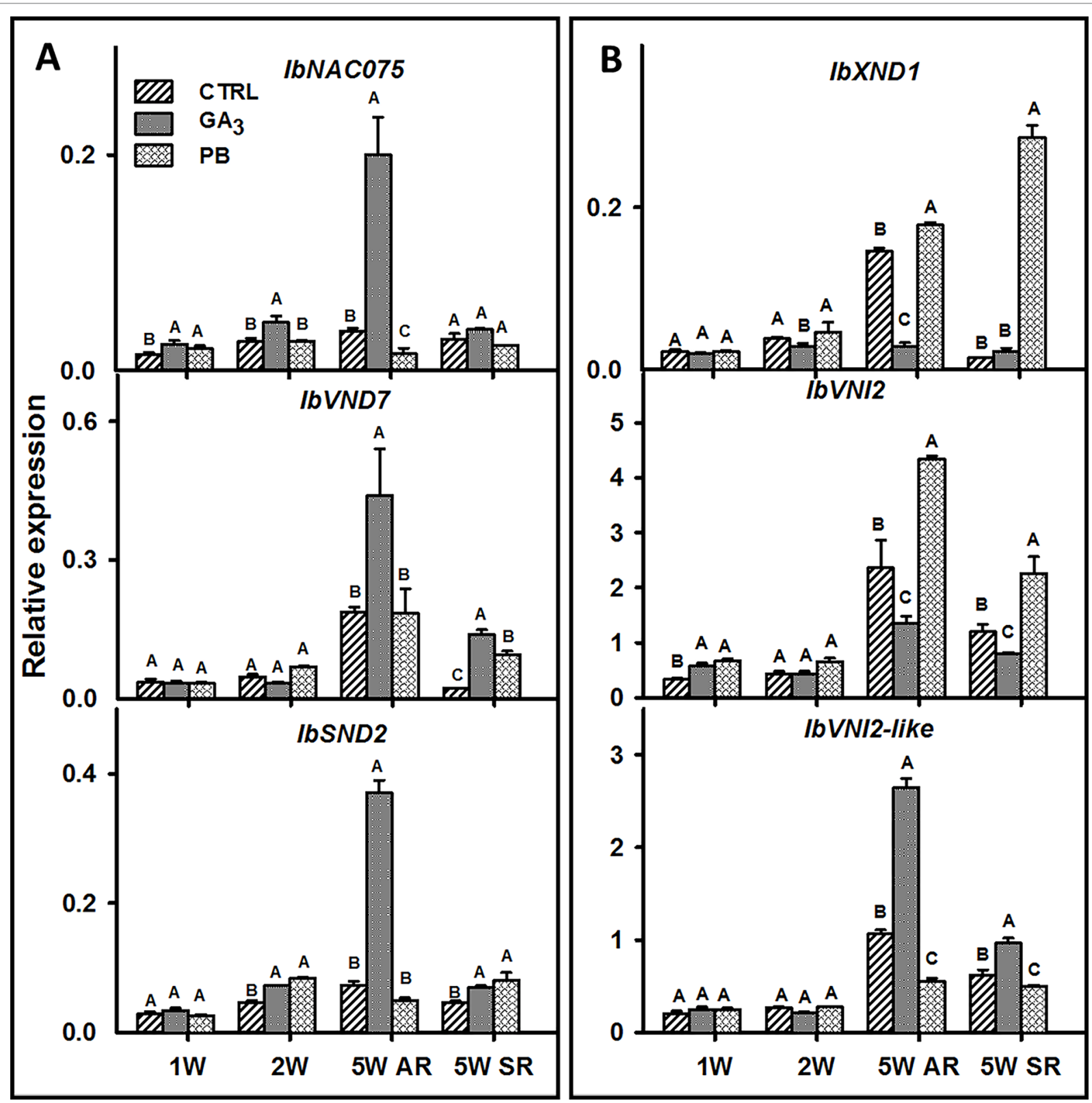

FIGURE 9 | The effect of $\mathrm{GA}_{3}$ application on expression profiles of sweetpotato "Georgia Jet" potential positive (A) and negative (B) regulators of vascular development in adventitious roots (AR) and storage-roots (SR). Expression/transcript levels were measured at 1W, $2 \mathrm{~W}$, and $5 \mathrm{~W}$ after planting for AR and at $5 \mathrm{~W}$ for SR, using qRT-PCR analyses, and values were normalized relative to the expression levels of phospholipase D1a. qRT-PCR data are mean ( \pm SE) of three independent biological replicates (each representing roots pooled from four plants). Significance analysis was performed by using student's $t$-test $(P \leq 0.05)$, where unlike letters represent significant differences between treatments within a group. Control (treated with water); $\mathrm{GA}_{3}$, application of 50 ppm gibberellic acid 3 for two weeks; PB, application of 5 ppm paclobutrazol for two weeks.

sweetpotato roots for enabling root system development. It should be mentioned in this context that other hormones, like auxin and cytokinin, are known to be involved in root growth and development and cross-talk between GA and different hormones was documented in various systems (Ogawa et al., 2003; Pacifci et al., 2015). In carrot root, for example, it was demonstrated that transcript levels of genes related to auxin, cytokinin, abscisic acid (ABA), and brassinolides were altered in response to increased or reduced gibberellins (Wang et al., $2015 b)$. In addition, an organ-specific regulation of hormonerelated genes in response to GA or PB was suggested (Wang et al., 2015b). Nonetheless, these results further substantiate the link between LR development and the capacity of the AR for SR formation (both being inhibited by $\mathrm{PB}$ application). 


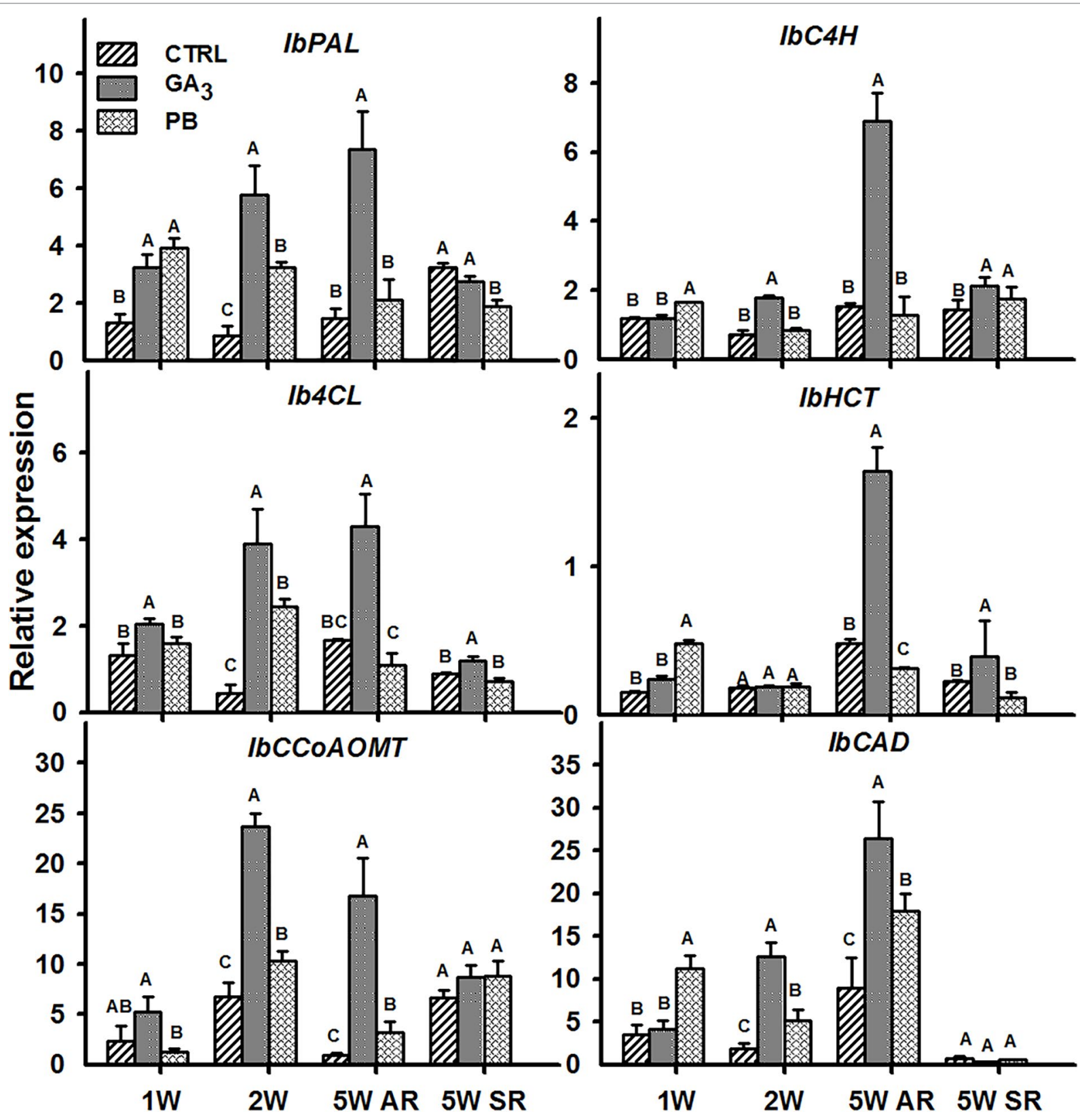

FIGURE 10 | The effect of $\mathrm{GA}_{3}$ application on expression profiles of sweetpotato "Georgia Jet" orthologues/genes of lignin biosynthesis in adventitious roots (AR) and storage-roots (SR). Expression/transcript levels were measured at 1W, 2W, and 5W after planting for AR and at 5W for SR, using qRT-PCR analyses, and values were normalized relative to the expression levels of phospholipase D1a. qRT-PCR data are mean $( \pm \mathrm{SE}$ ) of three independent biological replicates (each representing roots pooled from four plants). Significance analysis was performed by using student's t-test $(P \leq 0.05)$, where unlike letters represent significant differences between treatments within a group. Control (treated with water); $\mathrm{GA}_{3}$, application of 50 ppm gibberellic acid 3 for two weeks; PB, application of 5 ppm paclobutrazol for two weeks.

Gibberellin Has a Central Role in the Upregulation of Sweetpotato Root Xylem Formation and Lignification, and Downregulation of Starch Biosynthesis The Suggested Events Leading to Inhibition of Storage-Root Formation

Gibberellin was previously demonstrated to promote xylogenesis, induction of fiber production and fiber length, as well as lignification, in numerous plant systems including tobacco, carrot, and hybrid aspen (Eriksson et al., 2000; Biemelt et al., 2004; Dayan et al., 2010; Wang et al., 2017). In the presented work, in parallel to its promoting effect on xylem development and fiber formation, $\mathrm{GA}_{3}$ application caused induced lignification. Similar findings were reported recently in carrot taproot, demonstrating increased lignification following $\mathrm{GA}_{3}$ treatment (Wang et al., 2017). Exogenous application of $P B$, as opposed to $G_{3}$, did not induce secondary xylem and fiber formation, and its induction 


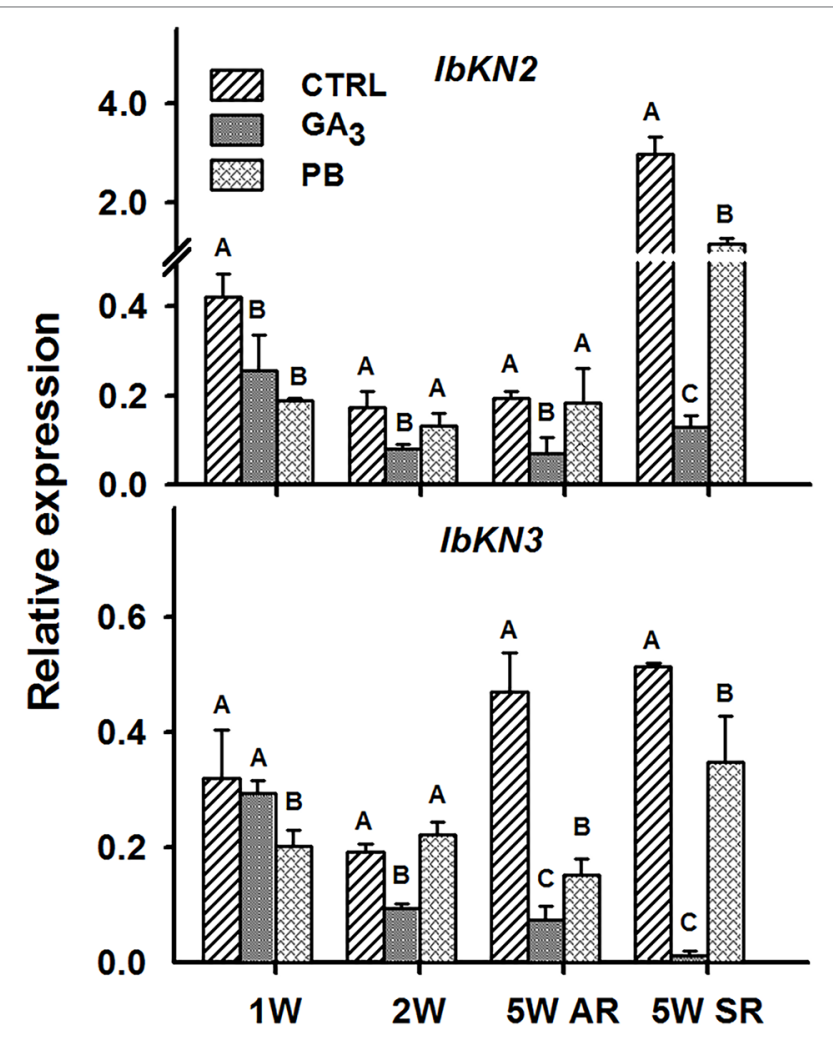

FIGURE 11 | The effect of $\mathrm{GA}_{3}$ application on expression profiles of sweetpotato "Georgia Jet" class I knotted 1-like orthologs/genes in adventitious roots (AR) and storage-roots (SR). Expression/transcript levels were measured at $1 \mathrm{~W}, 2 \mathrm{~W}$, and $5 \mathrm{~W}$ after planting for $\mathrm{AR}$ and at $5 \mathrm{~W}$ for SR, using qRT-PCR analyses, and values were normalized relative to the expression levels of phospholipase D1a. qRT-PCR data are mean ( \pm SE) of three independent biological replicates (each representing roots pooled from four plants). Significance analysis was performed by using student's t-test $(P \leq 0.05)$, where unlike letters represent significant differences between treatments within a group. Control (treated with water); $\mathrm{GA}_{3}$, application of 50 ppm gibberellic acid 3 for two weeks; $\mathrm{PB}$, application of 5 ppm paclobutrazol for two weeks.

of lignification was less pronounced. Paclobutrazol, in spite of its inhibitory effect on accumulation of bioactive GAs in the sweetpotato root system, exhibited a similar effect to $\mathrm{GA}_{3}$ with respect to enhancing significantly the number of root xylem vessels. Additional studies are thus needed in order to better understand the effect of $\mathrm{PB}$ on xylem development and lignin accumulation, as compared to $\mathrm{GA}_{3}$.

Togari (1950) proposed a direct link between root lignification and SR initiation, suggesting that lignification inhibits SR formation. Our results, together with studies in additional systems of SR development, like carrot and cassava, further strengthen the idea that lignification prevents SR formation. Such a relationship between stele lignification and inability of ARs to develop into SRs was pointed out in sweetpotato in additional studies (Wilson and Lowe, 1973; Belehu et al., 2004). Furthermore, transcription profiling in sweetpotato initiating SRs indicated down-regulation of lignin biosynthesis genes and up-regulation of carbohydrate metabolism and starch biosynthesis genes (Firon et al., 2013).
In the current study, $\mathrm{GA}_{3}$ application was found to cause both, upregulation of lignin accumulation and downregulation of starch levels in sweetpotato roots, being linked to inhibition of SR formation. We have previously suggested that major events involved in SR initiation are the reduction of carbon flow towards phenylpropanoid synthesis and its delivery into carbohydrate metabolism and starch biosynthesis (Firon et al., 2013). In the present work, $\mathrm{GA}_{3}$ may cause the opposite effect, namely reduction of carbon flow toward carbohydrate metabolism and delivery into phenylpropanoid and lignin synthesis. Gibberellin may also cause starch degradation as reported in Arabidopsis seeds where GA induced expression of an $\alpha$-amylase gene in developing seeds (Kim et al., 2005).

\section{Does the GA Inhibitory Effect on Storage-Root Development Operate Via Upregulation of Specific NAC-Domain Transcription Factors?}

The results of the current study point to GA as having a central role in regulating the main processes taking place during AR root development into either a lignified root or a storage organ. However, the molecular mechanisms underlying the regulation of these processes are not yet clear. In Arabidopsis, the NACdomain transcription factors, NAC075 and VND7, are master regulators of xylem development and secondary wall deposition including lignin (Endo et al., 2015). VND7, in turn, can regulate downstream NAC-domain genes like SND2 (Hussey et al., 2011), being upregulated by NAC075 (Endo et al., 2015), and inhibited by VNI2 (Yamaguchi et al., 2010) These genes, together with XND1 (negative regulator of xylem lignocellulose synthesis; Zhao et al., 2008) are thus good candidates to serve as regulators for mediating the GA effect on xylem development and lignin accumulation in sweetpotato roots. In accordance with increased root xylem development and lignification levels, $\mathrm{GA}_{3}$-treated plants exhibited induced transcript levels of the sweetpotato orthologues of Arabidopsis NAC075 and VND7 (IbNAC075 and IbVND7) genes, a corresponding increase in expression levels of IbSND2, as well as downregulation of IbVNI2 and IbXND1. Paclobutrazol application, opposed to $\mathrm{GA}_{3}$, caused significant down-regulation of IbNAC075 transcript levels. These results point to IbNAC075 and IbVND7 as potential master switches of root xylem proliferation and lignin biosynthesis, marking them as important candidates for future studies. Interestingly, MeVND7 was found in cassava to be expressed in fibrous/ lignified roots and not in SRs and was suggested as a regulator of xylem development (Siebers et al., 2017).

Previous studies demonstrated a correlation between changes in transcript levels of lignin biosynthesis genes and lignin accumulation (Zhong and Ye, 2009). In the system of carrot SR formation, it was recently found that exogenous GA enhanced lignin accumulation and induced the transcript levels of lignin biosynthesis genes, including PAL, 4CL, CCoAOMT, and $C A D$ (Wang et al., 2017). Highly increased levels of all tested sweetpotato orthologues of Arabidopsis lignin biosynthesis genes was detected in the sweetpotato root system, following $\mathrm{GA}_{3}$ application, correlating with the observed induction in lignin 


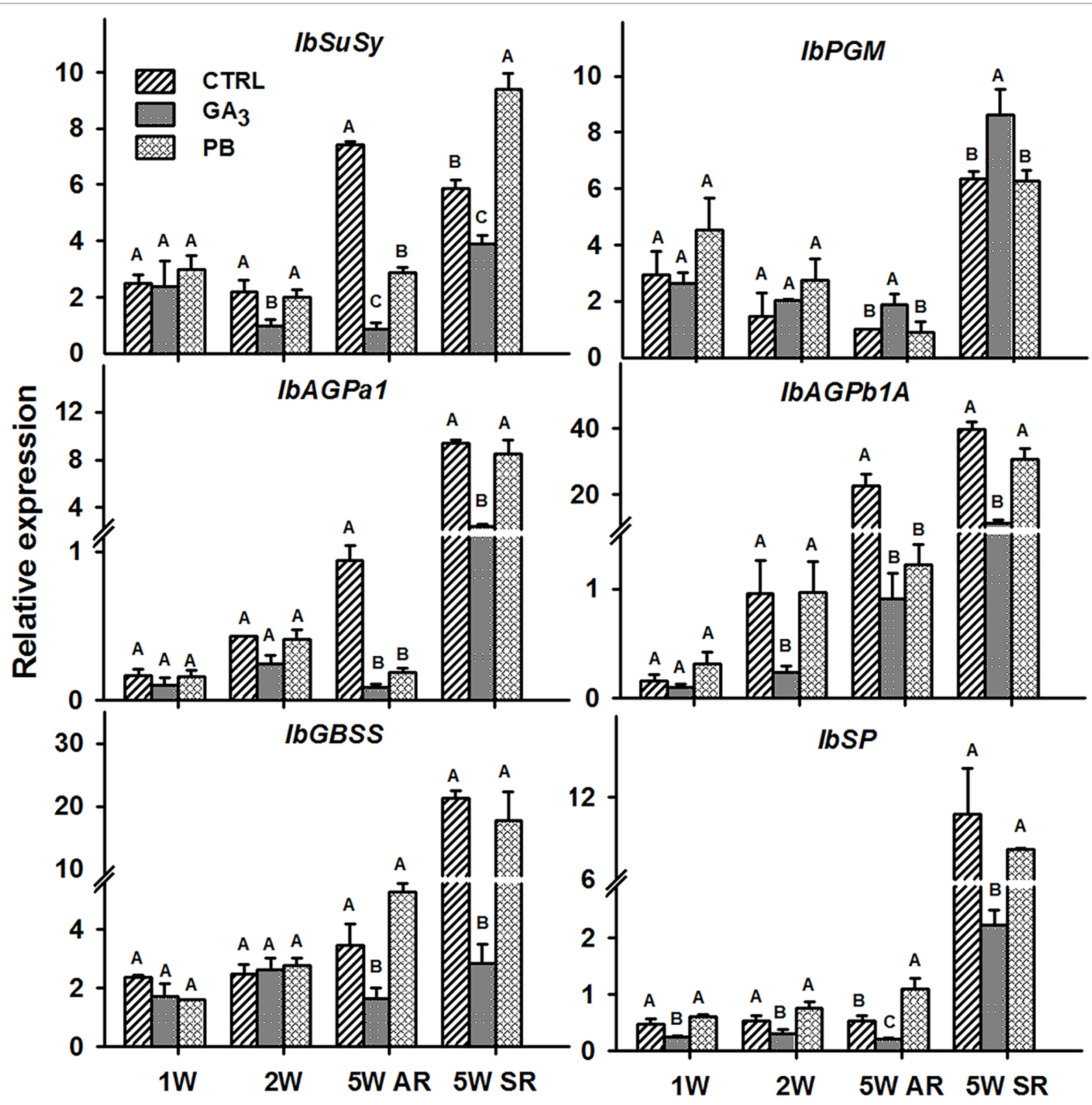

FIGURE 12 | The effect of $\mathrm{GA}_{3}$ application on expression profiles of sweetpotato "Georgia Jet" carbohydrate metabolism and starch biosynthesis orthologs/genes in adventitious roots (AR) and storage-roots (SR). Expression/transcript levels were measured at 1W, 2W and 5W after planting for AR and at 5W for SR, using qRTPCR analyses and values were normalized relative to the expression levels of phospholipase D1a. qRT-PCR data are mean ( \pm SE) of three independent biological replicates (each representing roots pooled from four plants). Significance analysis was performed by using student's t-test $(P \leq 0.05)$, where unlike letters represent significant differences between treatments within a group. Control (treated with water); $\mathrm{GA}_{3}$, application of $50 \mathrm{ppm}$ gibberellic acid 3 for two weeks; PB, application of 5 ppm paclobutrazol for two weeks.

accumulation. Such a correlation between lignin levels and gene expression of lignin biosynthesis genes (including $I b P A L, I b C L$, and $I b C A D$ ) was previously shown by us to exist in sweetpotato roots, when comparing between the transcriptome of lignified roots and roots exhibiting SR initiation (marked by development of "anomalous cambial cells"; Firon et al., 2013).

Another transcription factor that may serve as a good candidate for regulating sweetpotato root development and mediating the GA effect in yet another way is the KNOX1 gene. Interestingly, cross-talk between GA and KNOX genes was previously demonstrated in various systems (Hay et al., 2002). Knotted 1-like transcription factors are known regulators involved in the establishment and maintenance of plant meristems, found to be highly expressed in poplar cambial samples (Schrader et al., 2004) and to exhibit upregulated transcript levels in initiating SRs compared to lignified non-SRs 
(Firon et al., 2013). Such an interaction between GA and KNOX may affect the balance between lignification, on one hand, and meristem development, on the other hand, and may be highly relevant to the issue of SR formation. Mele et al. (2003) suggested in Arabidopsis that a KNOX1 gene, BP, regulates the lignin pathway, repressing premature cell differentiation. Hay et al. (2002) pointed out that reduced activity of the GA pathway promotes meristematic activity in Arabidopsis leaves. Such a transcription factor is thus a good candidate for serving as a regulator of SR development, operating at an intersection between downregulation of lignification and enabling upregulation of root cambium development. In accordance with this hypothesis, $\mathrm{GA}_{3}$ application caused a significant reduction in transcript levels of both $I b K N 2$ and $I b K N 3$ genes. Furthermore, $\mathrm{GA}_{3}$ treatment caused significant downregulation of carbohydrate metabolism and starch biosynthesis genes including genes encoding the small and large subunits ( $I b A G P a 1$ and $I b A G P b 1 A$ ) of the regulatory step in starch biosynthesis, conversion of glucose 1-phosphate and ATP to ADP-glucose and pyrophosphate by AGPase (Ballicora et al., 2004). It should be noted that Liebsch et al. (2014) showed that BP and STM weak mutants inhibit fiber formation in Arabidopsis hypocotyl and suggested that in the cambium, compared to the shoot meristem, KNOX genes (BP and STM) may have opposite consequences caused through different mechanisms. The effect of different levels of KNOX activity should be further studied in a variety of systems in order to better understand their function.

The significance of the current findings is illustrated by highlighting potential regulators/regulatory mechanisms that control SR formation in sweetpotato to be used for enhancing yield under variable growth conditions. A model is suggested (Figure 13), serving as a basis for further studies. According to this model, GA has a central and active role in upregulating the upstream master switches of xylem development and lignin biosynthesis, IbNAC075 and IbVND7 transcription factors, which in turn cause upregulation of yet another NAC domain containing regulator, IbSND2. This cascade leads to upregulation of lignin biosynthesis genes, causing high lignification of the AR and development of a non-SR. In parallel, GA downregulates KNOX1 genes and starch biosynthesis genes, highly reducing starch accumulation and inhibiting SR formation. GA also affects sweetpotato root system architecture, reducing LR number and LR length by an unknown mechanism. The results suggest that regulation of these processes in the root system is achieved at transcript level, and point to the respective genes as a valuable database for further studies, looking into/identifying the regulatory gene network. In addition, it is concluded that the response of sweetpotato roots to $\mathrm{PB}$ is complex, being opposite

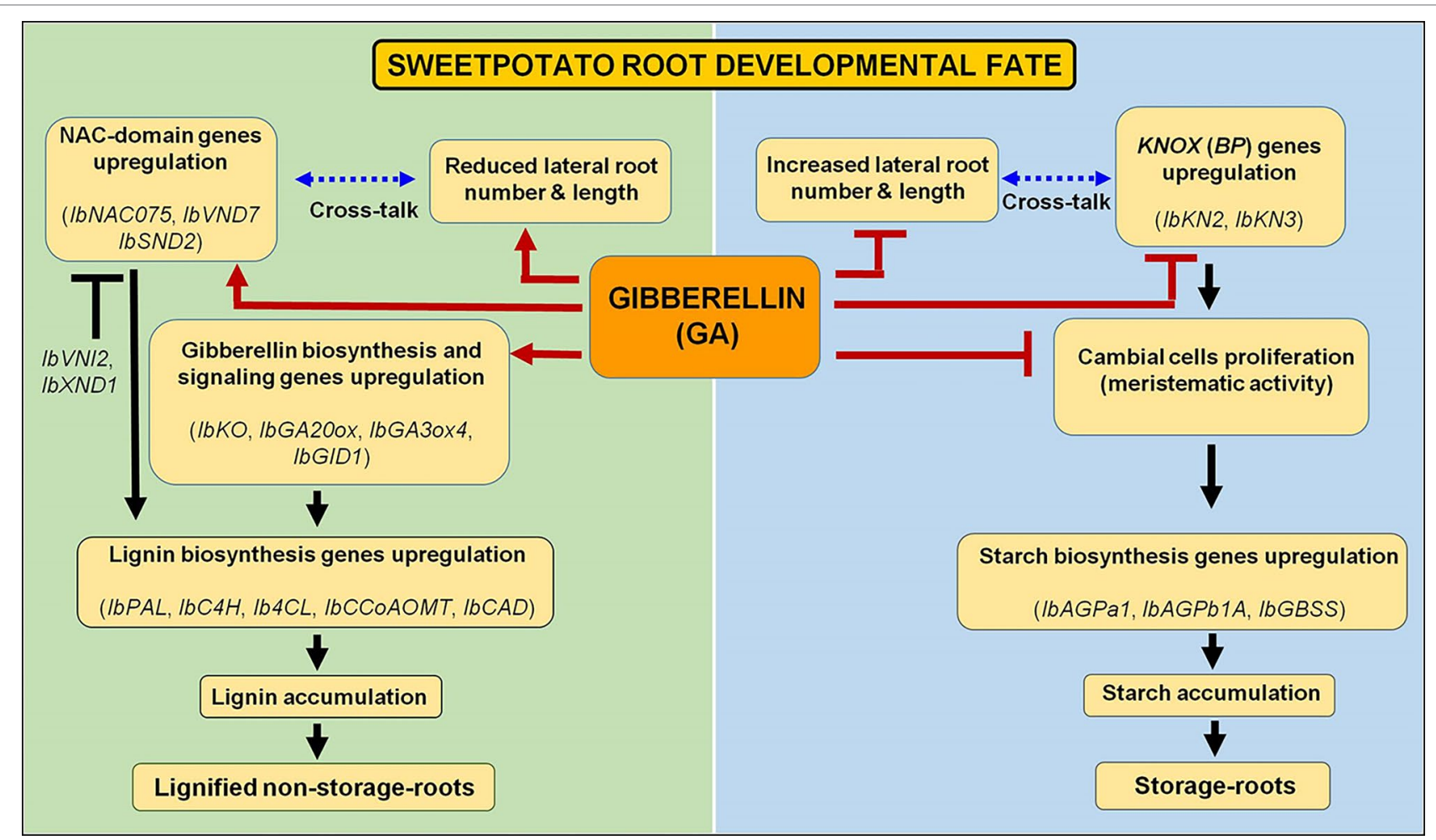

FIGURE 13 | Schematic presentation showing a central role for gibberellin (GA) in formation of either lignified non-storage roots or storage roots. Gibberellin enhances xylem development and proliferation, and lignin accumulation, following the upregulation of NAC-domain genes (regulators of vascular development), and lignin biosynthesis genes, together with reducing root system architecture and lateral root development, bringing about the formation of lignified non-storage roots. At the same time, GA inhibits transcript levels of KNOX genes and of genes involved in starch biosynthesis, followed by inhibition of starch accumulation, causing inhibition of the developmental pathway that brings about storage-root formation. Genes considered significant to the respective processes are indicated. 
to $\mathrm{GA}_{3}$ in some parameters (fiber formation, gene expression of IbGA20ox1, IbGA3ox4, IbGA2ox1, IbGAI, IbNAC075, IbXND1, and $I b H C T$ ) and similar to that of $\mathrm{GA}_{3}$, but attenuated, in other factors (lignification, SR number). These results may reflect the complex interactions/influence of $\mathrm{PB}$ as found in different/diverse plant systems, which include its effect on ABA, cytokinin, and stress tolerance (Tesfahun, 2018). Furthermore, it is hypothesized that environmental stress conditions will reduce SR yield by activating similar mechanisms. Thus, the genes/ mechanisms highlighted in the present study can serve for future experiments dealing with the molecular basis of the effect of stress on SR formation.

\section{DATA AVAILABILITY STATEMENT}

All datasets generated for this study are included in the article/ Supplementary Material.

\section{AUTHOR CONTRIBUTIONS}

VS and NF conceived and designed the experiments, analyzed the data, and wrote the manuscript. VS performed all the

\section{REFERENCES}

Ballicora, M. A., Iglesias, A. A., and Preiss, J. (2004). ADP-Glucose Pyrophosphorylase: a regulatory enzyme for plant starch synthesis. Photosyn. Res. 79, 1-24. doi: 10.1023/B:PRES.0000011916.0000067519.0000011958

Belehu, T., Hammes, P. S., and Robbertse, P. J. (2004). The origin and structure of adventitious roots in sweet potato (Ipomoea batatas). Aust. J. Bot. 52, 551-558. doi: 10.1071/BT03152

Biemelt, S., Tschiersch, H., and Sonnewald, U. (2004). Impact of altered gibberellin metabolism on biomass accumulation, lignin biosynthesis, and photosynthesis in transgenic tobacco plants. Plant Physiol. 135, 254-265. doi: 210.1104/ pp.1103.036988

Boerjan, W., Ralph, J., and Baucher, M. (2003). Lignin biosynthesis. Annu. Rev. Plant Biol. 54, 519-546. doi: 510.1146/annurev.arplant.1154.031902.134938

Bolduc, N., and Hake, S. (2009). The maize transcription factor KNOTTED1 directly regulates the gibberellin catabolism gene ga2ox1. Plant Cell. 21, 16471658. doi: 1610.1105/tpc.1109.068221

Bonawitz, N. D., and Chapple, C. (2010). The genetics of lignin biosynthesis: connecting genotype to phenotype. Annu. Rev. Genet. 44, 337-363. doi: 310.1146/annurev-genet-102209-163508

Chaffey, N., Cholewa, E., Regan, S., and Sundberg, B. (2002). Secondary xylem development in Arabidopsis: a model for wood formation. Physiol. Plant 114, 594-600. doi: 510.1034/j.1399-3054.2002.1140413.x

CIP.(2017). Harnessing potato and sweetpotatos power for food security, nutrition and climate resilience. Peru, Cecilia Lafosse. http://cipotato.org/annualreport2017/ wp-content/uploads/sites/7/2018/09/ANNUAL-REPORT-2017.pdf.

Dayan, J., Schwarzkopf, M., Avni, A., and Aloni, R. (2010). Enhancing plant growth and fiber production by silencing GA 2-oxidase. Plant Biotechnol. J. 8, 425-435. doi: 10.1111/j.1467-7652.2009.00480.x

Donaldson, L. A., and Knox, J. P. (2012). Localization of cell wall polysaccharides in normal and compression wood of radiata pine: relationships with lignification and microfibril orientation. Plant Physiol. 158, 642-653. doi: 610.1104/ pp.1111.184036

Duan, A. Q., Feng, K., Wang, G. L., Liu, J. X., Xu, Z. S., and Xiong, A. S. (2019). Elevated gibberellin enhances lignin accumulation in celery (Apium graveolens L.) leaves. Protoplasma. 256 (3), 777-788. doi: 10.1007/ s00709-00018-01341-00703. experiments. LS and WL performed gibberellin quantification. $\mathrm{HZ}$ helped in anatomical analyses. SS provided technical assistance in part of the experiments and starch analyses. AD-F did bioinformatics analysis. JY and ZP critically discussed the experiments and the results, and reviewed the manuscript. RA helped in interpretation of the anatomical data, vessel formation, and lignification. NF critically reviewed the manuscript. All the authors discussed the results and approved the manuscript.

\section{FUNDING}

We thank the Chief Scientist of The Ministry of Agriculture and Rural Development, Israel, Grant Agreement No. 20-10-0036 for supporting the research, in the frame of Israel-China collaboration.

\section{SUPPLEMENTARY MATERIAL}

The Supplementary Material for this article can be found online at: https://www.frontiersin.org/articles/10.3389/fpls.2019.01320/ full\#supplementary-material

Endo, H., Yamaguchi, M., Tamura, T., Nakano, Y., Nishikubo, N., Yoneda, A. et al. (2015). Multiple classes of transcription factors regulate the expression of VASCULAR-RELATED NAC-DOMAIN7, a master switch of xylem vessel differentiation. Plant Cell Physiol. 56, 242-254. doi: 210.1093/pcp/pcu1134

Eriksson, M. E., Israelsson, M., Olsson, O., and Moritz, T. (2000). Increased gibberellin biosynthesis in transgenic trees promotes growth, biomass production and xylem fiber length. Nat. Biotechnol. 18, 784-788. doi: $710.1038 / 77355$

FAOSTAT. (2017). Italy: FAO Publications. http://www.fao.org/3/b-i6407e.pdf.

Firon, N., LaBonte, D., Villordon, A., Kfir, Y., Solis, J., Lapis, E., et al. (2013). Transcriptional profiling of sweetpotato (Ipomoea batatas) roots indicates down-regulation of lignin biosynthesis and up-regulation of starch biosynthesis at an early stage of storage root formation. BMC Genomics 14, 460. doi: 410.1186/1471-2164-1114-1460

Geigenberger, P. (2011). Regulation of starch biosynthesis in response to a fluctuating environment. Plant Physiol. 155, 1566-1577. doi: 1510.1104/ pp.1110.170399

Geng, D., Chen, P., Shen, X., Zhang, Y., Li, X., Jiang, L., et al. (2018). MdMYB88 and MdMYB124 enhance drought tolerance by modulating root vessels and cell walls in apple. Plant Physiol. 178, 1296-1309. doi: 1210.1104/pp.1218.00502

Gou, J., Strauss, S. H., Tsai, C. J., Fang, K., Chen, Y., Jiang, X., et al. (2010). Gibberellins regulate lateral root formation in Populus through interactions with auxin and other hormones. Plant Cell. 22, 623-639. doi: 610.1105/ tpc.1109.073239

Guo, H., Wang, Y., Liu, H., Hu, P., Jia, Y., Zhang, C., et al. (2015). Exogenous GA3 application enhances xylem development and induces the expression of secondary wall biosynthesis related genes in Betula platyphylla. Int. J. Mole. Sci. 16, 22960-22975. doi: 22910.23390/ijms160922960

Gupta, R., and Chakrabarty, S. K. (2013). Gibberellic acid in plant: still a mystery unresolved. Plant Sig. Behav. 8, e25504. doi: 25510.24161/psb.25504

Hay, A., Kaur, H., Phillips, A., Hedden, P., Hake, S., and Tsiantis, M. (2002). The gibberellin pathway mediates KNOTTED1-type homeobox function in plants with different body plans. Curr. Biol. 12, 1557-1565. doi: 1510.1016/ S0960-9822(1502)01125-01129

Hedden, P., and Phillips, A. L. (2000). Gibberellin metabolism: new insights revealed by the genes. Trends Plant Sci. 5, 523-530. doi: 510.1016/ S1360-1385(1000)01790-01798 
Hellmann, E., Ko, D., Ruonala, R., and Helariutta, Y. (2018). Plant Vascular Tissues-connecting tissue comes in all shapes. Plants 7. (4), 109 doi: 110.3390/ plants7040109.

Hussey, S. G., Mizrachi, E., Spokevicius, A. V., Bossinger, G., Berger, D. K., and Myburg, A. A. (2011). SND2, a NAC transcription factor gene, regulates genes involved in secondary cell wall development in Arabidopsis fibres and increases fibre cell area in Eucalyptus. BMC Plant Biol. 11, 173. doi: 110.1186/1471-2229-1111-1173

Israelsson, M., Sundberg, B., and Moritz, T. (2005). Tissue-specific localization of gibberellins and expression of gibberellin-biosynthetic and signaling genes in wood-forming tissues in Aspen. Plant J. 44, 494-504. doi: 410.1111/j.1365-1313X.2005.02547.x

Kaneda, M., Rensing, K. H., Wong, J. C., Banno, B., Mansfield, S. D., and Samuels, A. L. (2008). Tracking monolignols during wood development in lodgepole pine. Plant Physiol., 147, 1750-1760. doi: 1710.1104/ pp.1108.121533

Kao, Y., Harding, S. A., and Tsai, C. J. (2002). Differential expression of two distinct phenylalanine ammonia-lyase genes in condensed tannin-accumulating and lignifying cells of quaking Aspen. Plant Physiol. 130, 796-807. doi: 710.1104/ pp.006262

Kim, Y. C., Nakajima, M., Nakayama, A., and Yamaguchi, I. (2005). Contribution of gibberellins to the formation of Arabidopsis seed coat through starch degradation. Plant Cell Physiol. 46, 1317-1325. doi: $1310.1093 / \mathrm{pcp} / \mathrm{pci} 1141$

Kim, Y. H., Hamayun, M., Khan, A. L., Na, C., Kang, S. M., Han, H. H., et al. (2009). Exogenous application of plant growth regulators increased the total flavonoid content in Taraxacum officinale Wigg. Afr. J. Biotechnol. 8, 57275732. doi: http://www.academicjournals.org/AJB

Kolachevskaya, O. O., Sergeeva, L., Flokova, K., Getman, I. A., Lomin, S. N., Alekseeva, V. V., et al. (2017). Auxin synthesis gene tms1 driven by tuberspecific promoter alters hormonal status of transgenic potato plants and their responses to exogenous phytohormones. Plant Cell Rep. 36, 419-435. doi: 410.1007/s00299-00016-02091-y

Kubo, M., Udagawa, M., Nishikubo, N., Horiguchi, G., Yamaguchi, M., Ito, J., et al. (2005). Transcription switches for protoxylem and metaxylem vessel formation. Genes Dev. 19, 1855-1860. doi: 1810.1101/gad.1331305

Liebsch, D., Sunaryo, W., Holmlund, M., Norberg, M., Zhang, J., Hall, H. C., et al. (2014). Class I KNOX transcription factors promote differentiation of cambial derivatives into xylem fibers in the Arabidopsis hypocotyl. Development 141, 4311-4319. doi: 4310.1242/dev.111369

Ma, J., Aloni, R., Villordon, A., Labonte, D., Kfir, Y., Zemach, H., et al. (2015). Adventitious root primordia formation and development in stem nodes of 'Georgia Jet' sweetpotato, Ipomoea batatas. Ame. J. Bot. 102, 1040-1049. doi: 1010.3732/ajb.1400505

MacRae, J. C. (1971). Quantitative measurement of starch in very small amounts of leaf tissue. Planta 96, 101-108. doi: 110.1007/BF00386360

Malamy, J. E., and Benfey, P. N. (1997). Organization and cell differentiation in lateral roots of Arabidopsis thaliana. Dev. 124, 33-44.

McGregor, C. E. (2006). Differential expression and detection of transcripts in sweetpotato (Ipomoea batatas (L.) Lam.) using cDNA microarrays. [PhD thesis]. USA: Louisiana State and Agricultural and Mechanical College.

Mele, G., Ori, N., Sato, Y., and Hake, S. (2003). The knotted1-like homeobox gene BREVIPEDICELLUS regulates cell differentiation by modulating metabolic pathways. Gen. Dev. 17, 2088-2093. doi: 2010.1101/gad.1120003

Mitra, P., and Loque, D. (2014). Histochemical staining of Arabidopsis thaliana secondary cell wall elements. J. Vis. Exp.: JoVE. 87, 51381. doi: $51310.53791 / 51381$

Mitsuda, N., Iwase, A., Yamamoto, H., Yoshida, M., Seki, M., Shinozaki, K., et al. (2007). NAC transcription factors, NST1 and NST3, are key regulators of the formation of secondary walls in woody tissues of Arabidopsis. Plant Cell. 19, 270-280. doi: 210.1105/tpc.1106.047043

Ogawa, M., Hanada, A., Yamauchi, Y., Kuwahara, A., Kamiya, Y., and Yamaguchi, S. (2003). Gibberellin biosynthesis and response during Arabidopsis seed germination. Plant Cell. 15, 1591-1604. doi: 1510.1105/tpc. 011650

Ohashi-Ito, K., Oda, Y., and Fukuda, H. (2010). Arabidopsis VASCULAR-RELATED NAC-DOMAIN6 directly regulates the genes that govern programmed cell death and secondary wall formation during xylem differentiation. Plant Cell. 22, 3461-3473. doi: 3410.1105/tpc.3110.075036
Olszewski, N., Sun, T., and Gubler, F. (2002). Gibberellin signaling: biosynthesis, catabolism, and response pathways. Plant Cell. 14, S61-S80. doi: 10.1105/ tpc. 010476

Pacifci, E., Polverari, L., and Sabatini, S. (2015). Plant hormone cross-talk: the pivot of root growth. J. Exp. Bot. 66, 1113-1121. doi: 10.1093/jxb/eru534

Park, S. C., Kim, Y. H., Ji, C. H., Park, S., Jeong, J. C., Lee, H. S., et al. (2012). Stable internal reference genes for the normalization of real-time PCR in different sweetpotato cultivars subjected to abiotic stress conditions. PloS One 7, e51502. doi: 10.1371/journal.pone.0051502

Peng, J., Carol, P., Richards, D. E., King, K. E., Cowling, R. J., Murphy, G. P., et al. (1997). The Arabidopsis GAI gene defines a signaling pathway that negatively regulates gibberellin responses. Genes Dev. 11, 3194-3205. doi: 10.1101/ gad.11.23.3194

Pomar, F., Merino, F., and Barcelo, A. R. (2002). O-4-Linked coniferyl and sinapyl aldehydes in lignifying cell walls are the main targets of the Wiesner (phloroglucinol-HCl) reaction. Protoplasma 220, 17-28. doi: 10.1007/ s00709-00002-00030-y

Rademacher, W. (2000). Growth Retardants: effects on gibberellin biosynthesis and other metabolic pathways. Ann. Rev. Plant Physiol. Plant Mol. Biol. 51, 501-531. doi: 510.1146/annurev.arplant.1151.1141.1501

Raes, J., Rohde, A., Christensen, J. H., de Peer, Y. V., and Boerjan, W. (2003). Genome-wide characterization of the lignification toolbox in Arabidopsis. Plant Physiol. 133, 1051-1071. doi: 1010.1104/pp.1103.026484

Ravi, V., Chakrabarti, S. K., Makeshkumar, T., and Saravanan, R. (2014) "Molecular regulation of storage root formation and development in sweet potato," in Horticultural Reviews. Ed. Janick, J. ( Hoboken, New Jersey: John Wiley \& Sons, Inc., Wiley-Blackwell), 157-207.

Ruzin, S. E. (1999). Plant microtechnique and microscopy. Oxford: Oxford University Press.

Schneider, C. A., Rasband, W. S., and Eliceiri, K. W. (2012). NIH Image to ImageJ: 25 years of image analysis. Nat. Met. 9, 671-675. doi: 10.1038/nmeth.2089

Schrader, J., Nilsson, J., Mellerowicz, E., Berglund, A., Nilsson, P., Hertzberg, M., et al. (2004). A high-resolution transcript profile across the wood-forming meristem of poplar identifies potential regulators of cambial stem cell identity. Plant Cell 16, 2278-2292. doi: 2210.1105/tpc.2104.024190

Scofield, S., and Murray, J. A. H. (2006). KNOX gene function in plant stem cell niches. Plant Mol. Biol. 60, 929-946. doi: 910.1007/s11103-11005-14478-y

Siebers, T., Catarino, B., and Agusti, J. (2017). Identification and expression analyses of new potential regulators of xylem development and cambium activity in cassava (Manihot esculenta). Planta 245, 539-548. doi: 510.1007/ s00425-00016-02623-00422

Sun, T. P. (2011). The molecular mechanism and evolution of the GA-GID1DELLA signaling module in plants. Curr. Biol. 21, R338-R345. doi: 310.1016/j. cub.2011.1002.1036

Tanaka-Ueguchi, M., Itoh, H., Oyama, N., Koshioka, M., and Matsuoka, M. (1998). Over-expression of a tobacco homeobox gene, NTH15, decreases the expression of a gibberellin biosynthetic gene encoding GA 20-oxidase. Plant J. 156, 391-400. doi: 310.1046/j.1365-1313X.1998.00217.x

Tanaka, M. (2016). Recent progress in molecular studies on storage root formation in sweetpotato (Ipomoea batatas). Jap. Agric. Res. Quart. JARQ 50, 293-299. doi: 210.6090/jarq.6050.6293

Tanaka, M., Katoa, N., Nakayamab, H., Nakatanic, M., and Takahata, Y. (2008). Expression of class I knotted1-like homeobox genes in the storage roots of sweetpotato (Ipomoea batatas). J. Plant Physiol. 165, 1726-1735. doi: 1710.1016/j.jplph.2007.1711.1009

Tang, N., Shahzad, Z., Lonjon, F., Loudet, O., Vailleau, F., and Maurel, C. (2018). Natural variation at XND1 impacts root hydraulics and trade-off for stress responses in Arabidopsis. Nat. Commu. 9, 3884. doi: 3810.1038/ s41467-41018-06430-41468

Taylor-Teeples, M., Lin, L., de Lucas, M., Turco, G., Toal, T. W., Gaudinier, A., et al. (2015). An Arabidopsis gene regulatory network for secondary cell wall synthesis. Nature 517, 571-575. doi: 510.1038/nature14099

Tesfahun, W. (2018). Response of crops to paclobutrazol application. Food Sci. Technol. 4, 1525169. doi: 10.1080/23311932.2018.1525169

Thomas, S. G., Phillips, A. L., and Hedden, P. (1999). Molecular cloning and functional expression of gibberellin 2-oxidases, multifunctional enzymes involved in gibberellin deactivation. Pro. Nat. Aca. Sci. 96, 4698-4703. doi: $10.1073 /$ pnas.96.8.4698 
Togari, Y. (1950). A study in the tuberous-root formation of sweet potato. Bull. Agric. Exp. Stat. Neb. 68, 1-96.

Villordon, A., La Bonte, D., Firon, N., Kfir, Y., Pressman, E., and Schwartz, A. (2009). Characterization of adventitious root development in sweetpotato. HortiSci. 44, 651-655. doi: 10.21273/HORTSCI.44.3.651

Villordon, A., LaBonte, D., Solis, J., and Firon, N. (2012). Characterization of lateral root development at the onset of storage root initiation in 'Beauregard' sweetpotato adventitious roots. HortSci. 47, 961-968. doi: 10.21273/HORTSCI.47.7.961

Villordon, A. Q., and Clark, C. A. (2014). Variation in virus symptom development and root architecture attributes at the onset of storage root initiation in 'Beauregard' sweetpotato plants grown with or without nitrogen. PloS One 9, e107384. doi: 107310.101371/journal.pone.0107384

Villordon, A. Q., Ginzberg, I., and Firon, N. (2014). Root architecture and root and tuber crop productivity. Trends Plant Sci. 19, 419-425. doi: 10.1016/j. tplants.2014.02.002

Vollbrecht, E., Reiser, L., and Hake, S. (2000). Shoot meristem size is dependent on inbred background and presence of the maize homeobox gene, knotted1. Dev. 127, 3161-3172.

Wang, G. L., Xiong, F., Que, F., Xu, Z., Wang, F., and Xiong, A. S. (2015a). Morphological characteristics, anatomical structure and gene expression: novel insights into gibberellin biosynthesis and perception during carot growth and development. Hort. Res. 2, 15028. doi: 0.1038/hortres.2015.28

Wang, G. L., Que, F., Xu, Z., Wang, F., and Xiong, A. S. (2015b). Exogenous gibberellin altered morphology, anatomic and transcriptional regulatory networks of hormones in carrot root and shoot. BMC Plant Biol. 15, 290. doi: 10.1186/s12870-015-0679-y

Wang, G. L., Que, F., Xu, Z. S., Wang, F., and Xiong, A. S. (2017). Exogenous gibberellin enhances secondary xylem development and lignification in carrot taproot. Protoplasma 254, 839-848. doi: 810.1007/s00709-00016-00995-00706

Wang, H., Yang, J., Zhang, M., Fan, W., Firon, N., Pattanaik, S., et al. (2016). Altered phenylpropanoid metabolism in the maize LcExpressed sweet potato (Ipomoea batatas) affects storage root development. Sci. Rep. 6, 18645. doi: 18610.11038/ srep 18645

Wang, S. Y., Sun, T., and Faust, M. (1986). Translocation of paclobutrazol, a gibberellin biosynthesis inhibitor in apple seedlings. Plant Physiol. 82, 11-14. doi: $10.1104 /$ pp.82.1.11

Wilson, L. A., and Lowe, S. B. (1973). The anatomy of the root system in West Indian Sweet potato [Ipomoea batatas (L.) Lam.] cultivars. Ann. Bot. 37, 633643. doi: 10.1093/oxfordjournals.aob.a084729

Yamaguchi, M., Kubo, M., Fukuda, H., and Demura, T. (2008). Vascularrelated NAC-DOMAIN7 is involved in the differentiation of all types of xylem vessels in Arabidopsis roots and shoots. Plant J. 55, 652-664. doi: 610.1111/j.1365-1313X.2008.03533.x
Yamaguchi, M., Ohtani, M., Mitsuda, N., Kubo, M., Ohme-Takagi, M., Fukuda, H., et al. (2010). VND-INTERACTING2, a NAC domain transcription factor, negatively regulates xylem vessel formation in Arabidopsis. Plant Cell. 22, 1249-1263. doi: 1210.1105/tpc.1108.064048

Yamaguchi, S. (2008). Gibberellin metabolism and its regulation. Ann. Rev. Plant Biol. 59, 225-251. doi: 210.1146/annurev.arplant.1159.032607.092804

Yang, J., An, D., and Zhang, P. (2011). Expression profiling of cassava storage roots reveals an active process of Glycolysis/Gluconeogenesis. J. Integ. Plant Biol. 53, 193-211. doi: 110.1111/j.1744-7909.2010.01018.x

Zhang, S., Zhang, D., Fan, S., Du, L., Shen, Y., Xing, L., et al. (2016). Effect of exogenous GA3 and its inhibitor paclobutrazol on floral formation, endogenous hormones, and flowering-associated genes in 'Fuji' apple (Malus domestica Borkh.). Plant Physiol. Biochem. 107, 178-186. doi: http://dx.doi. org/110.1016/j.plaphy.2016.1006.1005

Zhao, C., Avci, U., Grant, E. H., Haigler, C. H., and Beers, E. P. (2008). XND1, a member of the NAC domain family in Arabidopsis thaliana, negatively regulates lignocellulose synthesis and programmed cell death in xylem. Plant $J$. 53, 425-436. doi: 410.1111/j.1365-1313X.2007.03350.x

Zhong, R., and Ye, Z. H. (2009). Transcriptional regulation of lignin biosynthesis. Plant Sig. Behav. 4, 1028-1034. doi: 10.4161/psb.4.11.9875

Zhong, R., Demura, T., and Ye, Z. H. (2006). SND1, a NAC domain transcription factor, is a key regulator of secondary wall synthesis in fibers of Arabidopsis. Plant Cell. 18, 3158-3170. doi: 3110.1105/tpc.3106.047399

Zhong, R., Richardson, E. A., and Ye, Z. H. (2007). Two NAC domain transcription factors, SND1 and NST1, function redundantly in regulation of secondary wall synthesis in fibers of Arabidopsis. Planta 225, 1603-1611. doi: 1610.1007/ s00425-00007-00498-y

Zhou, J., Zhong, R., and Ye, Z. H. (2014). Arabidopsis NAC Domain Proteins, VND1 to VND5, are transcriptional regulators of secondary wall biosynthesis in vessels. PloS One 9, e105726. doi: 105710.101371/journal.pone.0105726

Conflict of Interest: The authors declare that the research was conducted in the absence of any commercial or financial relationships that could be construed as a potential conflict of interest.

Copyright $\odot 2019$ Singh, Sergeeva, Ligterink, Aloni, Zemach, Doron-Faigenboim, Yang, Zhang, Shabtai and Firon. This is an open-access article distributed under the terms of the Creative Commons Attribution License (CC BY). The use, distribution or reproduction in other forums is permitted, provided the original author(s) and the copyright owner(s) are credited and that the original publication in this journal is cited, in accordance with accepted academic practice. No use, distribution or reproduction is permitted which does not comply with these terms. 